\title{
Physiological responses of Manila clams Venerupis (=Ruditapes) philippinarum with varying parasite Perkinsus olseni burden to toxic algal Alexandrium ostenfeldii exposure
}

\author{
M. Lassudrie ${ }^{a}$, P. Soudant ${ }^{a}$, G. Richard ${ }^{a}$, N. Henry ${ }^{a}$, W. Medhioub ${ }^{a, b, c}$, P.M. da Silva ${ }^{d}$, A. Donval $^{a}$, \\ M. Bunel ${ }^{a}$, N. Le Goïc ${ }^{a}$, C. Lambert ${ }^{a}, X$. de Montaudouin ${ }^{e}$, C. Fabioux ${ }^{a, 1}, H^{2}$ Hégaret $^{a, 1, *}$
}

\begin{abstract}
a Laboratoire des Sciences de l'Environnement Marin (LEMAR), Institut Universitaire Européen de la Mer (IUEM), UBO/CNRS, rue Dumont d'Urville, technopôle Brest-Iroise, 29280 Plouzané, France

b Laboratoire Phycotoxines, Ifremer, Institut Français de Recherche pour l'Exploitation de la Mer, BP 21105, 44311 Nantes CEDEX3, France

${ }^{c}$ Laboratoire Milieu Marin, INSTM, Institut National des Sciences et Technologies de la Mer, 28 rue du 2 mars 1934, 2025 Salammbô, Tunisie

d Laboratory of Immunology and Pathology of Invertebrates, Department of Molecular Biology, Exact and Natural Sciences Center, Federal University of Paraíba - Campus I, 58051-900, João Pessoa, PB, Brazil

e Université de Bordeaux UMR 5805 EPOC, station marine d'Arcachon, 2 rue du Pr Jolyet, 33120 Arcachon, France

${ }^{1}$ Co-last authors.
\end{abstract}

*: Corresponding author : H. Hégaret, email adress : Helene.Hegaret@univ-brest.fr

\begin{abstract}
:
Manila clam stock from Arcachon Bay, France, is declining, as is commercial harvest. To understand the role of environmental biotic interactions in this decrease, effects of a toxic dinoflagellate, Alexandrium ostenfeldii, which blooms regularly in Arcachon bay, and the interaction with perkinsosis on clam physiology were investigated. Manila clams from Arcachon Bay, with variable natural levels of perkinsosis, were exposed for seven days to a mix of the nutritious microalga T-Iso and the toxic dinoflagellate $A$. ostenfeldii, a producer of spirolides, followed by seven days of depuration fed only TIso. Following sacrifice and quantification of protozoan parasite Perkinsus olseni burden, clams were divided into two groups according to intensity of the infection ("Light-Moderate" and "ModerateHeavy"). Hemocyte and plasma responses, digestive enzyme activities, antioxidant enzyme activities in gills, and histopathological responses were analyzed. Reactive oxygen species (ROS) production in hemocytes and catalase (CAT) activity in gills increased with $P$. olseni intensity of infection in control clams fed T-Iso, but did not vary among $A$. ostenfeldii-exposed clams. Exposure to A. ostenfeldii caused tissue alterations associated with an inflammatory response and modifications in hemocyte morphology. In the gills, superoxide dismutase (SOD) activity decreased, and an increase in brown cell occurrence was seen, suggesting oxidative stress. Observations of hemocytes and brown cells in tissues during exposure and depuration suggest involvement of both cell types in detoxication processes. Results suggest that exposure to $A$. ostenfeldii disrupted the pro-/anti-oxidant response of clams to heavy $P$. olseni intensity. In addition, depressed mitochondrial membrane potential (MMP) in hemocytes of clams exposed to $A$. ostenfeldii suggests that mitochondrial functions are regulated to maintain homeostasis of digestive enzyme activity and condition index.
\end{abstract}




\section{Highlights}

Exposure to $A$. ostenfeldii altered digestive glands and gills of Manila clams. Exposure to A. ostenfeldii was associated with an inflammatory response and oxidative stress. Exposure to $A$. ostenfeldii modulated both pro- and anti-oxidant responses to perkinsosis. Effects of exposure to $A$. ostenfeldii were induced by spirolides and/or extracellular products of the dinoflagellate.

Keywords : Bivalve ; Harmful algal bloom ; oxidative stress ; Venerupis philippinarum ; Alexandrium ostenfeldii ; Perkinsus olseni. 


\section{Introduction}

The Manila clam Venerupis (= Ruditapes) philippinarum is one of the most exploited bivalves in the world. Endemic to Indo-Pacific waters, it was introduced to the coast of France in the early 1970's for commercial purpose (Flassch and Leborgne, 1992). The Manila clam population from Arcachon Bay ranked first in France until 2012 (among the surveyed stocks) in terms of biomass (7,200 tons) and exploitable stock (720 tons) (Sanchez et al., 2013). The exploitable stock, however, is declining $(1,159$ tons in 2008, 916 tons in 2010), associated with decreasing harvests (Sanchez et al., 2013), causing a crisis for commercial fishermen. In this context, studies were conducted to understand the reason for this decrease and improve stock management. Although fishing is partially responsible (Dang et al., 2010b), effects of environmental factors remain to be investigated.

This population of clams is infected by the protozoan parasite Perkinsus olseni, with prevalences reaching high values (>90\%) (Dang et al., 2010a). The parasite P. olseni resides in the clam connective tissue and usually induces hemocytic infiltration and parasite encapsulation that may lead to milky-white cysts or nodules in heavily-infected clams (Choi et al., 2002; Lee et al., 2001). Immune responses of clams $V$. philippinarum to $P$. olseni infection involve changes in humoral and hemocyte characteristics (Soudant et al., 2013). Although P. olseni infection was associated with massive mortalities in cultured and wild Manila clams in South Korea (Choi and Park, 2010, 1997; Park and Choi, 2001), this parasite was not reported to affect clam populations along the French Atlantic coast severely (Dang, 2009).

Concurrently, Arcachon Bay is a site of recurring Harmful Algal Blooms (HABs). The "French Phytoplankton and Phycotoxin Monitoring Network" (REPHY, Ifremer) detects the repeated presence of Dinophysis sp., Pseudo-nitzschia sp. and Alexandrium sp., associated to DSP (Diarrheic Shellfish Poison), ASP (Amnesic Shellfish Poison), and PSP (Paralytic Shellfish Poison) toxins, respectively. For the first time in 2005, spirolides, a group of macrocyclic imine toxins, were detected in shellfish from Arcachon Bay (Amzil et al., 2007). These toxins were coincident with Alexandrium ostenfeldii blooms (data from REPHY). Despite the absence of toxic effects of spirolides reported to date in humans, these toxins are considered to be "fast-acting toxins" because of acute toxicity to mice following intra-peritoneal injection (Hu et al., 1995). Although mechanisms of spirolide action are not fully elucidated, studies focusing mainly on 13-desmethyl-C spirolide suggested that these compounds are antagonists of cholinergic nicotinic receptors in mammalian systems (Bourne et al., 2010; Gill et al., 2003; Hauser et al., 2012; Wandscheer et al., 2010), causing neurotoxic symptoms (Gill et al., 2003; Munday et al., 2012; Otero et al., 2012; Richard et al., 2001). To date, only one study 
documented the effect of $A$. ostenfeldii exposure on bivalves, showing that ingestion of this dinoflagellate by the Pacific oyster Crassostrea gigas caused an inflammatory response in the digestive gland, which is the main organ accumulating spirolides (Medhioub et al., 2012). Effects of other HAB species upon bivalves have been reported at different biological levels. Various effects upon general physiological processes (Cucci et al., 1985; Gainey and Shumway, 1988a, 1988b; Landsberg, 2002; Leverone et al., 2007; Shumway, 1990), on behavior (Gainey and Shumway, 1988b; Haberkorn et al., 2011; Hégaret et al., 2012; Shumway and Cucci, 1987; Tran et al., 2010), at tissue and cellular levels (da Silva et al., 2008; Galimany et al., 2008a, 2008b, 2008c; Haberkorn et al., 2010a, 2010b; Hégaret et al., 2007a, 2007b, 2007c), and more recently at the a molecular level (Estrada et al., 2007; Fabioux et al., subm.; Mello et al., 2013, 2012; Romero-Geraldo and HernándezSaavedra, 2012) have been observed. The first possible defense of bivalves against toxic or noxious particles in water is to close the valves and reduce filtration to minimize contact between microalgae and tissues (Gainey and Shumway, 1988b). There is, however, a balance between this protective response and the need for respiration and nutrition; consequently shell closure can be but a temporary response. The next line of defense in molluscan shellfish to noxious, harmful, or pathogenic agents is the immune system, involving humoral and cellular hemocyte responses which mediate internal defense mechanisms (Cheng, 1996; Song et al., 2010). Effects of HABs upon hemocyte morphology and functions have been reported (Hégaret and Wikfors, 2005a, 2005b; Hégaret et al., 2007a, 2007c; da Silva et al., 2008; Galimany et al., 2008a, 2008b, 2008c; Haberkorn et al., 2010a). Only few studies, however, have reported the effects of simultaneous exposures to HABs and pathogens upon bivalve physiology, although this phenomenon is common in the natural environment. Modifications of the host-pathogen interaction were observed after exposure of parasitized bivalves to toxic dinoflagellates (da Silva et al., 2008; Hégaret et al., 2009; Bricelj et al., 2011). In addition, the interaction of $\mathrm{HABs}$ and pathogens could lead to synergistic outcomes in bivalve physiology, affecting hemocyte functions (Bricelj et al., 2011; Hégaret et al., 2009, 2007a), but also inducing higher bivalve mortality rate, suggesting defeat of the defense system (Bricelj et al., 2011).

Manila clams from Arcachon Bay are likely to be subjected simultaneously to both perkinsosis and $A$. ostenfeldii exposure. This situation raises three questions: (i) What are the effects of different perkinsosis intensities? (ii) How does exposure to A. ostenfeldii affect clam physiology? (iii) Does exposure to A. ostenfeldii modifiy the host-pathogen interaction? To answer these questions, the effects upon different physiological responses of Manila clams caused by (i) varying natural P. olseni infection levels; (ii) experimental exposure of clams to A. ostenfeldii; and (iii) the combined effects of both biotic factors, were investigated. To describe the physiological responses of clams and identify the mechanisms underlying these responses, different biological levels and functions were studied, 
from individual to gene, with specific focus on digestive, immune, and mitochondrial functions, and pro-/anti-oxidative mechanisms. 
2. Materials and methods

\subsection{Experimental clams}

Manila clams, $V$. philippinarum of $32.7 \pm 0.3 \mathrm{~mm}$ shell length and $8.8 \pm 0.2 \mathrm{~g}$ live weight (mean \pm $\mathrm{SE}$ ), were collected from "Estey de Tessillat" station in Arcachon Bay, France, where high prevalence of P. olseni was recorded previously (Dang, 2009). Manila clams were collected on May $17^{\text {th }}, 2010$ and transferred the next day to IUEM, Plouzané, France, where the experiment was performed.

\subsection{Algal cultures}

The microalga Tisochrysis lutea (El M.Bendif \& I.Probert) (T-Iso), commonly provided as an aquaculture food for bivalves, was obtained from the Argenton hatchery (Ifremer, France) and was used as a control and a complementary diet for the experiment. T-Iso was cultured in $\mathrm{f} / 2$ medium (Guillard and Ryther, 1962) in 300-L open tanks, at $18^{\circ} \mathrm{C}$ with 24-h light. Batch cultures of T-Iso were harvested after 3 to 5 days of growth, usually at a cell density approaching $5 \times 10^{6}$ cells $\mathrm{mL}^{-1}$.

The Phycotoxin laboratory, Ifremer, Nantes (France), provided the toxic dinoflagellate Alexandrium ostenfeldii, strain CCMP1773 (isolated from Denmark), which is known to produce exclusively one type of toxin: spirolides (Otero et al., 2010). This strain was grown in L1 medium with soil extract (Guillard and Hargraves, 1993), and cultures were maintained at $16^{\circ} \mathrm{C}$ with 12 -h light in 20 -L carboys. Cells were harvested in stationary phase, usually at a cell density approaching $5-7 \times 10^{3}$ cells $\mathrm{mL}^{-1}$.

Algal cell densities were determined by counts using Nageotte cells under a light microscope.

\subsection{Experimental design and sampling}

One-hundred and twenty-eight clams were distributed randomly in eight $20-\mathrm{L}$ tanks (16 clams per tank) containing a 7-cm sediment layer of ultra-pure SILAQ silica sand (granulometry from 0.8 to 1.4 $\mathrm{mm}$ diameter) to allow clams to burrow. Before starting the experiment, clams were acclimated for one week, fed T-Iso $\left(5 \times 10^{5}\right.$ cells $\left.\mathrm{mL}^{-1}\right)$, in the $1-\mu \mathrm{m}$ filtered, flow-through seawater system used for the experiment ( $15 \mathrm{~L}$ per $24 \mathrm{~h}$ per tank, i.e. $10 \mathrm{~mL} \mathrm{~min}^{-1}$ ), at $16 \pm 1^{\circ} \mathrm{C}$, a temperature compatible with the transmission and development of infection by P. olseni (Villalba et al., 2004). 
Acclimation was followed by seven days of exposure to two different treatments with four replicates (i.e., 4 tanks) per treatment: (i) control clams, fed only T-Iso, at a concentration of $5 \times 10^{5}$ cells $\mathrm{mL}^{-1}$; (ii) HAB-exposed clams fed T-Iso at the same concentration with an addition of A. ostenfeldii at $10^{3}$ cells $\mathrm{mL}^{-1}$. Following this, a depuration period of seven days was applied during which clams were fed only T-Iso at $5 \times 10^{5}$ cells $\mathrm{mL}^{-1}$. Six clams per tank were sampled (i) at the end of exposure ( $\left.\mathrm{T}=14\right)$; and (ii) at the end of depuration ( $\mathrm{T}=21)$.

Hemocyte and plasma variables, condition index, histopathological condition, infection with P. olseni, activity of antioxidant and digestive enzymes, and toxin accumulation were analyzed at each sampling time.

\subsection{Analysis of hemocyte and plasma variables}

Hemolymph was withdrawn from the adductor muscle of each clam using a needle and a 1-ml syringe, filtered through an $80-\mu \mathrm{m}$ mesh, and stored temporarily in an Eppendorf microcentrifuge tube held on ice.

Hemocyte morphology and functions were analyzed on hemolymph extracted from each clam. Procedures for characterization of clam hemocytes, concentration (= total hemocyte counts - THC, cells $\mathrm{mL}^{-1}$ ), size, internal complexity and mortality of circulating hemocytes, as well as for functional responses, such as phagocytosis, unstimulated hemocyte production of reactive oxygen species (ROS) (specifically $\mathrm{O}_{2}{ }^{--}$and $\mathrm{H}_{2} \mathrm{O}_{2}$ ), and mitochondrial membrane potential (MMP) were adapted from Delaporte et al. (2003), Soudant et al. (2004) and Donaghy et al. (2012). Analyses of hemocytes were performed with a FACScalibur flow-cytometer (BD Biosciences, San Jose, CA).

In addition, remaining hemolymph was centrifuged $\left(800 \times \mathrm{g}, 5 \mathrm{~min}, 4^{\circ} \mathrm{C}\right)$ to be separated into two fractions: plasma (supernatant) and hemocytes (pellet), prior to freezing $\left(-20^{\circ} \mathrm{C}\right)$. Plasma was used for agglutination and hemolysis tests with horse red blood cells, following the protocol of Barracco et al. (1999), and expressed as the log (base 2) of the reciprocal of the highest dilution showing a positive pattern of agglutination or hemolysis of erythrocytes, respectively.

\subsection{Condition index $(\mathrm{CI})$}

Condition index (CI) of the Manila clams was calculated using the wet flesh weight (WFW) in relation to dry shell weight $(\mathrm{DSW})$ : $\mathrm{CI}=(\mathrm{WFW} / \mathrm{DSW}) \times 100$ (adapted from Bodoy et al., 1986). 


\subsection{Histopathological observations}

For histology, each clam was shucked, and two diagonally-slanted, 5-mm sections of soft tissue, including gills, mantle, digestive gland, intestine, and gonad, were excised. Additionally, a section of adductor muscle was sampled. Tissues were fixed immediately in Davidson's solution (Shaw and Battle, 1957) for $24 \mathrm{~h}$. Tissues then were transferred into $70 \%$ ethanol, dehydrated in ascending ethanol solutions, cleared with Claral ${ }^{\circledR}$, and embedded in paraffin wax. Five- $\mu \mathrm{m}$ sections were stained with Harris' hematoxylin and eosin (Howard et al., 2004) and observed under a light microscope.

A six-level, semi-quantitative scale was established to assess intensity of each histopathological condition observed, from 0 to 2.5 , as described in Table 1 .

\subsection{Detection and quantification of infection with $P$. olseni in V. philippinarum}

From each clam, after removing the section for histological studies, a portion of gills was excised and weighed. Gills were incubated in Ray's fluid-thioglycollate medium (RFTM, Ray 1966) for 7 days in the dark at room temperature and prepared to assess the parasite burden according to the protocol developed by Choi et al. (1989), as described in Hégaret et al. (2009). Briefly, gills were centrifuged $(800 \times \mathrm{g}, 10 \mathrm{~min})$ to remove medium and digested with $\mathrm{NaOH}\left(2 \mathrm{~N}, 1 \mathrm{~h}\right.$ at $60^{\circ} \mathrm{C}$, twice), followed by two washes in Phosphate-buffered saline (PBS) (0.1 M). Finally, the pellet was re-suspended in $1 \mathrm{~mL}$ of PBS. Ten microlitres of Lugol's solution was added, and the number of P. olseni hypnospores was counted using a Nageotte chamber under a light microscope.

The intensity of infection with $P$. olseni was calculated as the number of hypnospores per gram of wet weight of gill. To run multifactor statistical tests, the level of infection with $P$. olseni was divided into two equally-abundant classes: "Very light-Light" infection class $\left(<4.2 \times 10^{4}\right.$ P. olseni cells g ${ }^{-1}$ wet gill $)$ and "Moderate-High" infection class $\left(\geq 4.2 \times 10^{4}\right.$ P. olseni cells g ${ }^{-1}$ wet gills $)$.

\subsection{Activity of antioxidant enzymes}

The rest of the gills were removed and frozen immediately in liquid nitrogen after dissection, and stored at $-80^{\circ} \mathrm{C}$. Gill tissues were ground using a "Dangoumeau"-type ball grinder into liquid nitrogen. 


\section{Protein extraction:}

One fraction of $50 \mathrm{mg}$ of ground gills was homogenized, using an ultra-turrax, in $250 \mu \mathrm{L}$ of cold lysis buffer prepared following Guévélou et al. (2013) [ $\mathrm{NaCl} 150 \mathrm{mM}$, Tris $10 \mathrm{mM}, \mathrm{pH}$ 7.4, EDTA $1 \mathrm{mM}$, EGTA 1 mM, Phosphatase inhibitor cocktail II (Sigma-Aldrich) 0.01\%, Triton X-100 1\% v/v, CA-630 Igepal (Sigma-Aldrich) 0.5\%, 1 tablet of Complete EDTA-free protease inhibitor cocktail (Roche) were added extemporaneously per $25 \mathrm{~mL}$ buffer; $\mathrm{pH} 8.8$ at $4^{\circ} \mathrm{C}$ ] and centrifuged at $10,000 \mathrm{~g}$ for 45 $\min$ at $4{ }^{\circ} \mathrm{C}$. The supernatant then was stored at $-80^{\circ} \mathrm{C}$ until further analysis.

\section{Protein assay:}

Total protein content in gills was determined using the Bio-Rad DCTM Protein Assay, based upon the method of Lowry (Lowry et al., 1951) and appropriate for protein extracts containing detergents such as Triton X-100. Bovine serum albumin (Sigma-Aldrich) was used as protein standard. Absorbance at $750 \mathrm{~nm}$ was determined after $15 \mathrm{~min}$ of incubation at room temperature.

Activity of total Superoxide Dismutase (SOD), Mn SOD and Cu/Zn SOD:

Total superoxide dismutase (SOD; EC 1.15.1.1) activity in gills was measured using an SOD Assay Kit (Sigma-Aldrich) according to manufacturer's instructions. Protein extracts were diluted 40 times and absorbance at $440 \mathrm{~nm}$ was recorded after $20 \mathrm{~min}$ incubation at $25^{\circ} \mathrm{C}$. A standard inhibition curve was constructed using SOD from bovine erythrocytes (Sigma-Aldrich).

Mn SOD (= mitochondrial SOD) activity in gills was determined using the SOD Assay Kit and KCN (5 mM final concentration), a known inhibitor of the Cu/Zn SOD (= cytoplasmic SOD) (Fridovich, 1975; Manduzio et al., 2005). Protein extracts were diluted 5 times, and absorbance at $440 \mathrm{~nm}$ was recorded after $20 \mathrm{~min}$ of incubation at $25^{\circ} \mathrm{C}$.

$\mathrm{Cu} / \mathrm{Zn}$ SOD activity was evaluated as the difference between total SOD activity and Mn SOD activity.

Total SOD, Mn SOD and Cu/Zn SOD specific activities were expressed in $\mathrm{U} \mathrm{mg}^{-1}$ total proteins, one unit being defined as the amount of enzyme inhibiting by $50 \%$ the xanthine/xanthine oxidase complex.

\section{Activity of Catalase (CAT):}

Catalase (CAT; EC 1.11.1.6) activity in gills was determined following the method of Aebi (1984). Decrease in absorbance at $240 \mathrm{~nm}$ attributable to the decomposition of $\mathrm{H}_{2} \mathrm{O}_{2}(10 \mathrm{mM})$ was recorded at 9-s intervals for 90 s. Protein extracts were diluted 200 times and CAT-specific activities were 
expressed in $\mathrm{U} \mathrm{mg}^{-1}$ total proteins, one unit of CAT being defined as the amount of enzyme catalyzing $1 \mu \mathrm{mol}$ of $\mathrm{H}_{2} \mathrm{O}_{2} \min ^{-1}$.

\subsection{Activity of digestive enzymes}

\section{Protein extraction:}

Digestive gland stored at $-80^{\circ} \mathrm{C}$ immediately after sampling was homogenized using a Potter in phosphate buffer $0.02 \mathrm{M}\left(0.02 \mathrm{M} \mathrm{NaH}_{2} \mathrm{PO}_{4} / 0.02 \mathrm{M} \mathrm{Na}_{2} \mathrm{HPO}_{4}\right)\left(100 \mathrm{mg}\right.$ wet weight $\left.\mathrm{mL}^{-1}\right)$, and centrifuged at $4,000 \times \mathrm{g}$ for $30 \mathrm{~min}$. Supernatant was stored at $-80^{\circ} \mathrm{C}$ until further analyses.

\section{Protein assay:}

To assess specific activity of digestive enzymes, protein extracts were diluted at $1 / 20$ in phosphate buffer $0.02 \mathrm{M}$, and total protein content was determined with a Bio-Rad Protein Assay, based on the Bradford method (Bradford, 1976) using Bovine Serum Albumin as a protein standard.

\section{Activity of amylase, cellulase and laminarinase:}

Activities of digestive enzymes were assessed using the method of Bernfeld (1955) slightly modified. Activities of amylase, cellulase and laminarinase were measured, by incubating diluted protein supernatants at $37^{\circ} \mathrm{C}$ (dilution in phosphate buffer $0.02 \mathrm{M}$ : $1 / 20$ for amylase, $1 / 2$ for cellulase, $1 / 4$ for laminarinase) with the sugar they reduce: starch (30 min of incubation), cellulose $(1 \mathrm{~h})$, and laminarin $(1 \mathrm{~h})$, respectively. After the reaction was stopped by adding $250 \mu \mathrm{L}$ of 3,5-dinitrosalicylic acid (3,5DNS), samples were boiled for $15 \mathrm{~min}$ to enable the reduction of 3,5-DNS in 3-amino-5-nitrosalicylic acid, producing a coloration proportional to the quantity of sugar reduced, and absorbance was read spectrophotometrically at $540 \mathrm{~nm}$. Specific activity was determined using maltose standards ranging from 0.2 to $1.0 \mathrm{mg} \mathrm{mL}^{-1}$ and expressed in $\mathrm{mg}$ of maltose liberated $\mathrm{mg}^{-1}$ proteins $\mathrm{h}^{-1}$.

\subsection{Toxin accumulation}

Accumulation of spirolides was measured at each sampling time on 8 exposed individuals ( 2 per tank) and 2 control individuals in two fractions of soft tissue: digestive gland and remaining tissues (including siphon, foot, gills, adductor muscle and mantle), that had been frozen in liquid nitrogen 
immediately after sampling, then stored at $-80^{\circ} \mathrm{C}$. Lipophilic toxins were extracted in methanol/water (95/5) and analyzed by LC-MS/MS at the EMP/PHYC laboratory of Ifremer, Nantes, France, as described in Amzil et al. (2007) and Medhioub et al. (2012).

\subsection{Statistical analyses}

T-test $(\alpha=0.05)$ was used to compare total spirolide accumulation between clams from algal treatments (T-Iso vs. A. ostenfeldii), sampling times (exposure vs. depuration), or tissues (digestive gland vs. remaining tissues), and one-way ANOVA followed by Tukey HSD post-hoc test ( $\alpha=0.05$ ) was used to assess differences in accumulation between the three spirolide analogues.

To assess the effect of time of experiment (exposure or depuration), algal treatment, and level of infection with $P$. olseni and their interactions on hemocyte variables and enzyme activities, a 3-way ANOVA (type 3 Sum of Squares) was performed, in which above factors were independents. After determining that the effect of the time during experiment was not significant, data from algal treatments and perkinsosis categories were analyzed using values from all sampling times of the experiment combined. In addition, to identify specific responses upon exposure or depuration, data were analyzed separately at each sampling time, using a 2-way ANOVA (type 3 Sum of Squares), in which algal treatment and level of infection with $P$. olseni were independent factors. When the effect of the interaction was significant, the Tukey HSD post-hoc test was used to identify differences between treatment means. Effects attributable to $P$. olseni burden were combined from the duration of the experiment.

When needed, data were transformed $(\log$ or $1 / \mathrm{X})$ prior to analysis to meet homoscedasticity and normality assumptions.

For histopathology results, a unilateral Mann-Whitney $U$ test $(\alpha=0.1)$ was used to assess the effect of $P$. olseni burden over the duration of the experiment, and to assess the effect of algal treatment over the entire time of experiment, and separately after exposure and after depuration period.

Statistics were performed with Statgraphics Plus statistical software (Manugistics, Inc., Rockville, $\mathrm{MD}$,

USA). 


\section{Results}

\subsection{Perkinsus olseni burden in clam gills}

Prevalence of perkinsosis in experimental clams was $100 \%$, and mean intensity of infection was $7.7 \pm$ $0.9 \times 10^{4}$ cells $\mathrm{g}^{-1}$ wet gills (mean $\pm \mathrm{SE}$ ). The mean intensity of infection of each class, "Very lightLight" (46 clams) and "Moderate-High" (45 clams), was $1.3 \pm 0.2 \times 10^{4}$ and $14 \pm 1 \times 10^{4}$ P. olseni cells $\mathrm{g}^{-1}$ wet gills (mean $\pm \mathrm{SE}$ ), respectively.

P. olseni burden was not significantly affected by exposure to A. ostenfeldii but showed a decreasing trend. The mean intensity of infection of all clams sampled was $6.6 \pm 1.0 \times 10^{4}$ cells g $^{-1}$ wet gills (47 clams) in A. ostenfeldii exposed individuals, and was $8.8 \pm 1.6 \times 10^{4}$ cells $\mathrm{g}^{-1}$ wet gills (44 clams) in control clams (mean $\pm \mathrm{SE}$ ).

\subsection{Toxin quantification}

Three spirolide analogues were identified and quantified within the tissues: 13, 19-didesmethyl-C (13, 19-didesMeC), 13-desmethyl-C (13-desMeC) and 13-desmethyl-D (13-desMeD). Mean accumulation of total spirolides was significantly higher in the digestive gland than in the remaining tissues at both sampling times $(\mathrm{p}<0.001)$. In both digestive gland and remaining tissues, and at both sampling times, accumulation of total spirolides was significantly higher in dinoflagellate-exposed individuals $(4.0 \pm$ $0.7 \times 10^{2} \mu \mathrm{g}$ 13-desMeC eq. $\mathrm{kg}^{-1}$ in digestive gland and $2.1 \pm 0.3 \times 10^{2} \mu \mathrm{g}$ 13-desMeC eq. $\mathrm{kg}^{-1}$ in remaining tissues) compared to controls, in which only 13 -desMeC was detected $\left(2.9 \pm 0.1 \times 10^{1} \mu \mathrm{g} 13\right.$ desMeC eq. $\mathrm{kg}^{-1}$ in digestive gland and $2.6 \pm 0.2 \times 10^{1} \mu \mathrm{g}$ 13-desMeC eq. $\mathrm{kg}^{-1}$ in remaining tissues) $(p<0.05$ in digestive gland at both sampling times; $p<0.01$ after exposure in remaining tissues; $p<0.001$ after depuration in remaining tissues). Among spirolide analogues, only the 13, 19-didesMeC decreased significantly after seven days of depuration in both digestive gland and remaining tissues of A. ostenfeldii-exposed clams ( $\mathrm{p}<0.001$ in digestive gland; $\mathrm{p}<0.01$ in remaining tissues), leading to a significant decrease in total spirolide content in both digestive gland and remaining tissues $(\mathrm{p}<0.05)$ (Figure 1). 
3.3 Condition index, hemocyte and plasma variables, digestive and antioxidant enzyme specific activities

Results of statistical analyses are summarized in Table 2. Effects of algal treatment are presented over the entire experiment (both sampling times combined), after 7 days exposure, and after 7 days of depuration. Effects attributable to $P$. olseni burden are presented over the entire experiment as well as effects of algal treatment and $P$. olseni burden interaction (because no significant effect was detected at each sampling time).

\section{Condition index}

Condition index of experimental clams did not vary with algal treatment or intensity of $P$. olseni infection.

\section{Hemocyte and plasma analyses}

Although granulocytes and hyalinocytes have already been described by cytochemical assays in Manila clams (Cima et al., 2000), morphological distinction between clam hemocyte types using flow cytometry is not always successful (Donaghy et al., 2009). Consequently, in this study, granulocytes and hyalinocytes were analyzed together.

Total hemocyte count (THC), internal complexity of hemocytes, phagocytosis, hemocyte mortality, agglutination and hemolysis titer did not vary significantly between the different experimental treatments.

Exposure to A. ostenfeldii led to an increase in the mean size of hemocytes, which was significant after exposure and over the duration of the experiment (Figure 2 A). Mean size of hemocytes also increased significantly with $P$. olseni burden, from $133 \pm 1$ a.u. (arbitrary units) in "Very lightly-Lightly" infected clams to $137 \pm 1$ a.u. in "Moderately-Highly" infected clams (mean \pm SE).

Mitochondrial membrane potential (MMP) of hemocytes decreased significantly in clams exposed for 7 days to A. ostenfeldii (Figure 2 B).

A significant interaction of both algal treatment and $P$. olseni burden was detected throughout the experiment for ROS production in hemocytes. In individuals exposed to the non-toxic T-Iso, ROS production in "Very lightly-Lightly" infected clams was significantly lower than in "ModeratelyHighly" infected clams (Figure $2 \mathrm{C}$ ). 


\section{Digestive enzyme specific activities}

No significant effect was observed on specific activities of amylase, cellulase or laminarinase for algal treatment or intensity of $P$. olseni infection.

Antioxidant enzyme activities in gills

Total SOD specific activity was significantly lower in gills of clams exposed to A. ostenfeldii over the entire experiment, mostly attributable to the significant difference detected after depuration between control and exposed animals (Figure $3 \mathrm{~A}$ ). The specific activites of both SOD isoforms $\mathrm{Cu} / \mathrm{Zn}$ and $\mathrm{Mn}$ SOD, comprised in total SOD, were also significantly lower in gills of clams exposed to A. ostenfeldii throughout the experiment.

A significant effect of the interaction of $P$. olseni burden and algal treatment was identified (Figure 3 B) upon specific activity of CAT in gills. After exposure to T-Iso, CAT specific activity was higher in "Moderately-Highly" infected clams than in "Very lightly-Lightly" infected ones, but this response was not observed in A. ostenfeldii-exposed clams.

\subsection{Histopathological effects}

Effects of algal treatment over the entire experiment (both sampling times combined), after seven days of exposure and after seven days of depuration, and effects of $P$. olseni burden upon histological features of experimental clams are reported in Table 3.

To identify effects of A. ostenfeldii exposure upon clam tissues, intensities of pathologies first were compared between all clams exposed to A. ostenfeldii and all control clams sampled throughout the experiment. Exposure to A. ostenfeldii caused a decrease in hemocyte infiltration into the digestive gland $(\mathrm{p}<0.05)$, as well as an increase in edema in the mantle $(\mathrm{p}<0.05)$, vacuolation in the gills $(\mathrm{p}<0.1)$ (Figure 4 A, B), hemocyte diapedesis into the intestine $(\mathrm{p}<0.05)$ (Figure 4 D, E), and epithelium sloughing into the stomach lumen $(\mathrm{p}<0.1)$. These pathologies were associated with observations of $A$. ostenfeldii cells within the intestinal lumen (Figure $4 \mathrm{E}$ ) after both exposure and depuration in exposed clams. 
After seven days of exposure to A. ostenfeldii, hemocyte infiltration in gills ( $\mathrm{p}<0.05)$ (Figure $5 \mathrm{~A}$ ), edema in the mantle $(\mathrm{p}<0.05)$ (Figure $5 \mathrm{~B}$ ), and epithelium sloughing into the intestinal lumen increased $(\mathrm{p}<0.05)$ (Figure $5 \mathrm{C}$ ), while hemocyte infiltration into the digestive gland decreased $(\mathrm{p}<0.01)$. In addition, A. ostenfeldii cells were observed in digestive tubules of one individual after seven days of exposure (Figure 4 F). After seven days of depuration, an increased intensity of cell vacuolation in gill filaments $(\mathrm{p}<0.1)$ (Figure 4 A, B; Figure 5 D) and of brown cells $(\mathrm{p}<0.1)$ (Figure 4 A; C; Figure 5 E), as well as an increased number of hemocytes in the intestinal lumen (Figure 5 F), were observed in A. ostenfeldii-exposed clams.

Histopathological observations showed that clams with "Moderate-Heavy" P. olseni burden, had more intense vacuolation in digestive tubules $(\mathrm{p}<0.1)$ (Figure $4 \mathrm{G}, \mathrm{H})$ compared to "Very lightly-Lightly" infected individuals, as well as more hemocytic encapsulation bodies in gonadal tissue $(\mathrm{p}<0.1)$ and in the digestive gland $(\mathrm{p}<0.1)$ (Figure $4 \mathrm{I})$. These pathologies were associated with a higher number of Perkinsus cells observed in the digestive gland $(\mathrm{p}<0.05)$ (Figure $4 \mathrm{I})$.

Exposure to A. ostenfeldii resulted in a decrease in Perkinsus cells observed in clam tissues. Indeed, significantly fewer Perkinsus cells were observed in gills of clams throughout the experiment $(\mathrm{p}<0.1)$, in mantle $(\mathrm{p}<0.01)$ after seven days of exposure, and in adductor muscle $(\mathrm{p}<0.1)$ after the depuration period, compared to clams fed to T-Iso. 


\section{Discussion}

This study revealed physiological and histological consequences of variable parasite, Perkinsus olseni, infestation intensities upon Manila clams, Venerupis philippinarum, effects of exposure to the toxic dinoflagellate Alexandrium ostenfeldii upon the clams, and interactive effects as well. Consideration of two microbiological interactions in individual clams highlights the fact that these interactions occur in nature, although they may not be considered in controlled experiments that are designed to eliminate potentially confounding independent variables. Considering parasite and harmful algal effects individually and combined provided a better indication of the compound challenges that confront clams in nature, but this consideration also makes untangling causes and effects a complex task. Accordingly, we proceed by discussing individual responses of clams to parasitism or to harmfulalgal-exposure, finally interpreting interactive responses.

\subsection{Effects of P. olseni}

Overall, effects of higher $P$. olseni infections were relatively light and did not affect important physiological functions of clams. Although the digestive gland showed evidence of tissue damage, i.e. vacuolation in digestive tubules, digestive functions were maintained, as shown by the representative digestive enzyme activities analyzed. Furthermore, presence of encapsulation bodies highlighted the effectiveness of the immune response, allowing other cellular and humoral immune responses, such as phagocytosis, hemolytic activity or agglutination titer, to occur. Encapsulation is indeed believed to be an important mechanism by which clams defend against $P$. olseni (Chagot et al., 1987; Montes et al., 1996, 1995; Navas et al., 1992; Ordás et al., 2001; Park and Choi, 2001; Sagrista et al., 1995). The increase in size of circulating hemocytes detected in our study could reflect cell differentiation for this immune response. These light effects can be attributed to the relatively low intensity of $P$. olseni infection compared to other studies. Waki and Yoshinaga (2013) and Waki et al. (2012) suggested that P. olseni pathogenicity to the Manila clam was considerable at a level of $\sim 10^{6}$ cells $^{-1}$ soft tissues, above which mortality occurred. Although such intensity levels are frequent in Manila clam populations in Asia (Choi and Park, 2010), mean P. olseni burdens reported in French populations usually do not exceed $10^{5}$ cells $\mathrm{g}^{-1}$ of soft tissue (Binias et al., 2014, 2013; da Silva et al., 2008; Dang et al., 2013; de Montaudouin et al., 2010; Hégaret et al., 2007a), with no seasonal variation (Binias et al., 2014; Dang et al., 2013, 2010a), in contrast to other locations such as Gomso Bay, Korea (Yang et al., 2012) or Galicia, Spain (Villalba et al., 2005). Accordingly, Hégaret et al. (2007a, 2009) and da Silva et al. (2008), did not observed significant effects of $P$. olseni upon most of the hemocytic 
variables they measured in French Manila clams. For this intensity of infection, an explanation suggested by Hégaret et al. (2007a) is that, once the host hemocytes have accomplished isolation of the parasite, the remaining circulating hemocytes resume the main functions. No effects of parasite burden upon condition index or mortality of clams were observed, thus confirming that the global host-pathogen interaction remained in equilibrium.

\subsection{Effects of A. ostenfeldii exposure}

After exposure of experimental Manila clams to the toxic dinoflagellate A. ostenfeldii, spirolide analogues accumulated preferentially in the digestive gland, as reported in oysters by Medhioub et al. (2012), but also in the remaining tissues including siphon, foot, gills, muscle and mantle. In addition, the 13-desmethyl-C spirolide was detected at very low levels in control clams, showing that these clams had been exposed to A. ostenfeldii in the field. Indeed, since 2005, spirolides have been detected recurrently by the "French Phytoplankton and Phycotoxin monitoring Network" (REPHY) in tissues of oysters and mussels from Arcachon Bay and were attributed to A. ostenfeldii blooms.

After seven days exposure, overall effects of exposure to A. ostenfeldii on clam "external" (mantle and gills) and "internal" organs (digestive gland) were identified. As clams are filter feeders, the first contact of microalgae with tissues occurs through siphons (not investigated in this study), mantle, and gills. Contact with A. ostenfeldii led to edema in the mantle, associated with hemocyte infiltration in the gills, indicating an inflammatory response. We suggest that the increase in hemocyte size is attributed to a differentiation process associated to this inflammatory response. These effects may be induced partly by the spirolides released after lysis of A. ostenfeldii cells during digestion and accumulated in tissues. As mantle and gills were in contact with living A. ostenfeldii cells, however, these tissues also may have been exposed to algal extracellular compounds. Indeed, independently from spirolides, A. ostenfeldii is able to produce extracellular compounds known to provoke immobilization and cell lysis of protists (Tillmann et al. 2007). Other Alexandrium species were reported to produce extracellular compounds with allelopathic, hemolytic, and ichthyotoxic properties (Arzul et al., 1999; Lelong et al., 2011; Ogata and Kodama, 1986; Simonsen et al., 1995) or oxidative properties (Flores et al., 2012). These compounds also can be deleterious to bivalves, as demonstrate by Ford et al. (2008) upon hemocyte functions. Ingestion of A. ostenfeldii cells, as observed on histological slides, was followed by deleterious effects upon internal organs, such as digestive epithelium sloughing into the intestinal lumen. In addition, the presence of intact $A$. ostenfeldii cells in the digestive tubules, where at least partially digested particles normally are found, and observation of 
A. ostenfeldii within the intestinal lumen after seven days of depuration, suggest partial dysfunction of digestive processes. Medhioub et al. (2012) also observed failure to digest A. ostenfeldii cells by oysters $C$. gigas and hemocyte diapedesis through the digestive epithelium. A role of hemocyte diapedesis after harmful algal exposure was suggested by other authors as a mechanism to eliminate toxin through the lumen of the intestine and/or to isolate Alexandrium cells (Galimany et al., 2008c; Haberkorn et al., 2010b; Hégaret et al., 2009). The detection of yessotoxin (another phycotoxin) in hemocytes of contaminated mussels by Franchini et al. (2003) strengthen the hypothesis that these cells could transport toxins out of the tissues as a detoxication process.

After a seven-day depuration time, spirolide content in digestive glands and remaining tissues of $A$. ostenfeldii- exposed clams decreased. Toxins, mainly 13-desmethyl-C spirolide, however, still were present in tissues, which could explain observations again of hemocytes undergoing diapedesis into the intestine and present in the lumen, consistent with our hypothesis that hemocytes participate in the detoxication process. In clam gill filaments, the harmful-algal exposure followed by a depuration period induced cell-vacuolation that probably affected gill functions, reflecting a persistent deleterious effect of A. ostenfeldii toxic compounds, extracellular compounds or spirolides. Alterations in gills were associated with higher amounts of brown cells (also referred to as ceroid bodies), suggesting oxidative stress, as these cells contain lipofuscin-like pigments constituted of non-degradable material, resulting mainly from the accumulation of oxidized proteins and lipids (Yin, 1996). Other authors also observed induction of brown cells in bivalve tissues following harmful-algal exposure (Galimany et al., 2008b), but also in response to organic pollutant exposure (Lehmann et al., 2007; Morado and Mooney, 1997; Smolowitz and Leavitt, 1996). In addition, brown cells from the "red gland" or pericardial gland of bivalves have been shown to play a role in accumulation, detoxication, and degradation of pollutants (Zaroogian and Anderson, 1995; Zaroogian and Yevich, 1994; Zaroogian et al., 1989). In the present study, we suggest that the brown cells observed within gills indicated oxidative stress, and these cells may in addition participate in detoxication. Another indicator of possible oxidative stress in gills was the depression of total SOD specific activity, an antioxidant enzyme, as reported by Estrada et al. (2007) in gills of Nodipecten subnodosus exposed to the toxic dinoflagellate Gymnodinium catenatum and associated with lipid peroxidation. Exposure to A. minutum also presumably provoked oxidative stress in $C$. gigas gills, detected by measurement of antioxidant enzyme transcript levels (Fabioux et al. subm.). In this study, the decrease in mitochondrial SOD (Mn SOD) activity measured in gills of A. ostenfeldii- exposed clams may indicate mitochondrial metabolic adjustments to maintain homeostasis, as suggested by Romero-Geraldo and Hernández-Saavedra (2012). These authors observed an overall repression in antioxidant enzyme transcript levels, including SOD, in $C$. gigas for the first 14 days of exposure to toxic dinoflagellate 
Prorocentrum lima. The decrease of MMP in hemocytes in our study also supports the involvement of mitochondrial adjustments.

4.3 Modulation of $P$. olseni burden responses in clam pro-/anti-oxidative mechanisms by exposure to A. ostenfeldii

Exposure to A. ostenfeldii led to higher ROS production in hemocytes of "Very lightly-Lightly" infected clams. In addition, ROS production also increased in hemocytes of clams fed T-Iso as a response to the higher intensity of $P$. olseni infection. Changes in CAT activity within gills were concomitant with changes in circulating hemocyte ROS production, suggesting a protective response against higher production of ROS. These ROS compounds measured in unstimulated hemocytes probably originate from mitochondria, as shown in unstimulated hemocytes of $C$. gigas (Donaghy et al., 2012). ROS produced by mitochondria are involved in the modulation of many cellular processes such as cell signaling, immune responses, apoptosis, or ion-channel functions (Bartosz, 2009; Stowe and Camara, 2009). The increase in ROS production observed in our experiment may thus either play a role in the response to $P$. olseni infection and/or to A. ostenfeldii exposure by inducing modifications in cellular processes or it may be a consequence of physiologically-related mitochondrial changes (Stowe and Camara, 2009) induced by the parasitic infection and/or the algal exposure. No variation in ROS production, however, was observed in hemocytes of $A$. ostenfeldii-exposed clams with higher $P$. olseni infestation, suggesting that ROS production reached a threshold or that exposure to $A$. ostenfeldii is able to neutralize the increase in ROS stimulated by $P$. olseni.

\subsection{Effect of A. ostenfeldii exposure on P. olseni burden in tissues of Manila clams}

Although exposure to A. ostenfeldii did not modify $P$. olseni gill burden in experimental clams, a decreasing trend was observed, which also was confirmed by histological observations. P. olseni observations significantly decreased in gills, mantle and adductor muscle, suggesting a deleterious effect of A. ostenfeldii upon the parasite. In another study exposing Manila clams to the harmful alga Karenia selliformis, $P$. olseni infection intensity regressed in toxic algal-exposed clams, suggesting a negative effect of this alga upon $P$. olseni (da Silva et al., 2008). In vitro experiments confirmed that $K$. selliformis had negative effects upon $P$. olseni viability, modifying the host-pathogen interaction (da Silva et al., 2008). In vitro experiments also demonstrated detrimental effects of another dinoflagellate, $P$. minimum and its exudates, upon $P$. olseni cells (Hégaret et al., 2009). It would thus 
be interesting to assess the direct effect of $A$. ostenfeldii on $P$. olseni cells to understand the observed effects of A. ostenfeldii exposure upon the parasite occurrence within tissues. 


\section{Conclusions}

Overall, hemocyte immune functions of Manila clams remained relatively unchanged according to perkinsosis level and A. ostenfeldii exposure, highlighting the capacity of clams to maintain homeostasis. Indeed, despite histological damage and partial dysfunction of the digestive gland caused by A. ostenfeldii exposure, digestive enzyme activities were not affected, showing that clams were able to maintain these main nutritional functions. Modifications in mitochondrial metabolism and detoxication processes probably participated in maintaining homeostasis. From this study, it appears that the interaction of A. ostenfeldii blooms and perkinsosis does not likely affect survival of Manila clam stocks from Arcachon Bay. Considering the roles of hemocytes in immunity, however, the question of a potential consequence of changes in hemocyte morphology and MMP induced by exposure to A. ostenfeldii on clam capacity to defend against other more virulent pathogens or other environmental stressors cannot be excluded. 
Conflict of interest

Authors have nothing to declare.

Acknowledgments

The authors are grateful to Patrick Lassus and Michèle Bardouil from Phycotoxin laboratory, Ifremer, Nantes (France) and Luc Lebrun from Argenton hatchery, Ifremer, (France) for providing algal strains and cultures. We thank also Edouard Kraffe for his constructive comments on the manuscript and Gary H. Wikfors for suggestions on the manuscript and English corrections.

This study was funded by Program LITEAU 3 of the French Environment Ministry (Project REPAMEP). M. Lassudrie was supported by a doctoral grant from Université de Bretagne Occidentale.

Author contribution

Conceived and designed the experiment: PS, NLG, CL, XM, CF, HH. Performed the analyses: ML, PS, GR, NH, WM, PMS, AD, MB, NLG, CL, CF, HH. Analyzed the data: ML, PS, GR, NH, HH. Wrote the paper: ML, PS, PMS, CF, HH. 


\section{References}

Aebi, H., 1984. Catalase in Vitro. Methods Enzymol. 105, 121-126.

Amzil, Z., Sibat, M., Royer, F., Masson, N., Abadie, E., 2007. Report on the first detection of pectenotoxin-2, spirolide-A and their derivatives in French shellfish. Mar. Drugs 5, 168-179.

Arzul, G., Seguel, M., Guzman, L., Erard-Le Denn, E., 1999. Comparison of allelopathic properties in three toxic Alexandrium species. J. Exp. Mar. Bio. Ecol. 232, 285-295.

Barracco, M.A., Medeiros, I.D., Moreira, F.M., 1999. Some haemato-immunological parameters in the mussel Perna perna. Fish Shellfish Immunol. 9, 387-404.

Bartosz, G., 2009. Reactive oxygen species: destroyers or messengers? Biochem. Pharmacol. 77, 1303-1315.

Bernfeld, P., 1955. Amylases, alpha and beta, in: Methods in Enzymology I. Academic Press, New York, pp. 149-158.

Binias, C., Gonzalez, P., Provost, M., Lambert, C., de Montaudouin, X., 2014. Brown muscle disease: impact on Manila clam Venerupis (=Ruditapes) philippinarum biology. Fish Shellfish Immunol. $36,510-518$.

Binias, C., Do, V.T., Jude-Lemeilleur, F., Plus, M., Froidefond, J.M., de Montaudouin, X., 2013. Environmental factors contributing to the development of brown muscle disease and perkinsosis in Manila clams (Ruditapes philippinarum) and trematodiasis in cockles (Cerastoderma edule) of Arcachon Bay. Mar. Ecol. doi: 10.1111/maec.12087

Bodoy, A., Prou, J., Berthome, J.-P., 1986. Etude comparative des différents indices de conditions chez l'huître creuse (Crassostrea gigas). Haliotis 15, 173-182.

Bourne, Y., Radic, Z., Aráoz, R., Talley, T.T., Benoit, E., Servent, D., Taylor, P., Molgó, J., Marchot, P., 2010. Structural determinants in phycotoxins and AChBP conferring high affinity binding and nicotinic AChR antagonism. Proc. Natl. Acad. Sci. U. S. A. 107, 6076-6081. 
Bradford, M.M., 1976. A rapid and sensitive method for the quantitation microgram quantities of protein utilizing the principle of protein-dye binding. Anal. Biochem. 72, 248-254.

Bricelj, V.M., Ford, S.E., Lambert, C., Barbou, A., Paillard, C., 2011. Effects of toxic Alexandrium tamarense on behavior, hemocyte responses and development of brown ring disease in Manila clams. Mar. Ecol. Prog. Ser. 430, 35-48.

Chagot, D., Comps, M., Boulo, V., Ruan, F., Grizel, H., 1987. Histological study of a cellular reaction in Ruditapes decussatus infected by a protozoan. Aquaculture 67, 260-261.

Cheng, T.C., 1996. Haemocytes: Forms and functions, in: Kennedy, V., Newell, R., Eble, A. (Eds.), The Eastern Oyster Crassostrea Virginica. College Park: Maryland Sea Grant, pp. 299-333.

Choi, K.S., Park, K.I., 1997. Report on the Occurrence of Perkinsus sp. in the Manila Clams, Ruditapes philippinarum in Korea. Korean J. Aquac. 10, 227-237.

Choi, K.S., Park, K.I., 2010. Review on the Protozoan parasite Perkinsus olseni (Lester and Davis 1981) infection in asian waters, in: Ishimatsu, A., Lier, H.-J. (Eds.), Coastal Environmental and Ecosystem Issues of the East China Sea. TERRABUP; Nagasaki university, pp. 269-281.

Choi, K.S., Park, K.I., Lee, K.W., Matsuoka, K., 2002. Infection intensity, prevalence, and histopathology of Perkinsus sp. in the Manila clam, Ruditapes philippinarum, in Isahaya Bay, Japan. J. Shellfish Res. 21, 119-126.

Choi, K.S., Wilson, E.A., Lewis, D.H., Powell, E.N., Ray, S.M., 1989. The energetic cost of Perkinsus marinus parasitism in oysters: quantification of the thioglycollate method. J. Shellfish Res. 8, $125-131$.

Cima, F., Matozzo, V., Marin, M.G., Ballarin, L., 2000. Haemocytes of the clam Tapes philippinarum (Adams \& Reeve, 1850): morphofunctional characterisation. Fish Shellfish Immunol. 10, 677693.

Cucci, T.L., Shumway, S.E., Newell, R.C., Yentsch, M., 1985. A preliminary study of the effects of Gonyaulax tamarensis on feeding in bivalve molluscs, in: Anderson, D.M., White, A.W., Baden, D.G. (Eds.), Toxic Dinoflagellates. Elsevier/North-Holland, Amsterdam, pp. 395-400.

da Silva, P.M., Hégaret, H., Lambert, C., Wikfors, G.H., Le Goïc, N., Shumway, S.E., Soudant, P., 2008. Immunological responses of the Manila clam (Ruditapes philippinarum) with varying 
parasite (Perkinsus olseni) burden, during a long-term exposure to the harmful alga, Karenia selliformis, and possible interactions. Toxicon 51, 563-573.

Dang, C., 2009. Dynamique des populations de palourdes japonaises (Ruditapes philippinarum) dans le bassin d'Arcachon, conséquences sur la gestion des popultions exploitées. Ph.D. Thesis; Université de Bordeaux 1.

Dang, C., de Montaudouin, X., Binias, C., Salvo, F., Caill-Milly, N., Bald, J., Soudant, P., 2013. Correlation between perkinsosis and growth in clams Ruditapes spp. Dis. Aquat. Organ. 106, $255-265$.

Dang, C., de Montaudouin, X., Caill-Milly, N., Trumbic, Z., 2010a. Spatio-temporal patterns of perkinsosis in the Manila clam Ruditapes philippinarum from Arcachon Bay (SW France). Dis. Aquat. Organ. 91, 151-159.

Dang, C., de Montaudouin, X., Gam, M., Paroissin, C., Bru, N., Caill-Milly, N., 2010b. The Manila clam population in Arcachon Bay (SW France): Can it be kept sustainable? J. Sea Res. 63, 108118.

De Montaudouin, X., Paul-Pont, I., Lambert, C., Gonzalez, P., Raymond, N., Jude, F., Legeay, a, Baudrimont, M., Dang, C., Le Grand, F., Le Goïc, N., Bourasseau, L., Paillard, C., 2010. Bivalve population health: multistress to identify hot spots. Mar. Pollut. Bull. 60, 1307-1318.

Delaporte, M., Soudant, P., Moal, J., Lambert, C., Quéré, C., Miner, P., Choquet, G., Paillard, C., Samain, J.F., 2003. Effect of a mono-specific algal diet on immune functions in two bivalve species - Crassostrea gigas and Ruditapes philippinarum. J. Exp. Biol. 206, 3053-3064.

Donaghy, L., Kraffe, E., Le Goïc, N., Lambert, C., Volety, A.K., Soudant, P., 2012. Reactive oxygen species in unstimulated hemocytes of the Pacific oyster Crassostrea gigas: A mitochondrial involvement. PLoS One 7, 1-10.

Donaghy, L., Lambert, C., Choi, K.S., Soudant, P., 2009. Hemocytes of the carpet shell clam (Ruditapes decussatus) and the Manila clam (Ruditapes philippinarum): Current knowledge and future prospects. Aquaculture 297, 10-24.

Estrada, N., de Jesús Romero, M., Campa-Córdova, A., Luna, A., Ascencio, F., 2007. Effects of the toxic dinoflagellate, Gymnodinium catenatum on hydrolytic and antioxidant enzymes, in tissues 
of the giant lions-paw scallop Nodipecten subnodosus. Comp. Biochem. Physiol. Part C 146, $502-510$.

Fabioux, C., Sulistiyani, Y., Haberkorn, H., Hégaret, H., Soudant, P., submitted. Exposure to toxic Alexandrium minutum activates the antioxidant and detoxifying systems of the oyster Crassostrea gigas.

Flassch, J.P., Leborgne, Y., 1992. Introduction in Europe, from 1972 to 1980, of the Japanese Manila clam (Tapes philippinarum) and the effects on aquaculture production and natural settlement. ICES mar. Sci. Symp. 194, 92-96.

Flores, H.S., Wikfors, G.H., Dam, H.G., 2012. Reactive oxygen species are linked to the toxicity of the dinoflagellate Alexandrium spp. to protists. Aquat. Microb. Ecol. 66, 199-209.

Ford, S.E., Bricelj, V.M., Lambert, C., Paillard, C., 2008. Deleterious effects of a nonPST bioactive compound(s) from Alexandrium tamarense on bivalve hemocytes. Mar. Biol. 154, 241-253.

Franchini, A., Milandri, A., Poletti, R., Ottaviani, E., 2003. Immunolocalization of yessotoxins in the mussel Mytilus galloprovincialis. Toxicon 41, 967-970.

Fridovich, I., 1975. Superoxide Dismutases. Annu. Rev. Biochem. 44, 147-159.

Gainey, L.F., Shumway, S.E., 1988. Physiological effects of Protogonyaulax tamarensis on cardiac activity in bivalves molluscs. Comp. Biochem. Physiol. Part C 91, 159-164.

Gainey, L.F., Shumway, S.E., 1988b. A compendium of the responses of bivalve molluscs to toxic dinoflagellates. J. Shellfish Res. 7, 623-628.

Galimany, E., Place, A.R., Ramon, M., Jutson, M., Pipe, R.K., 2008a. The effects of feeding Karlodinium veneficum (PLY \# 103; Gymnodinium veneficum Ballantine) to the blue mussel Mytilus edulis. Harmful Algae 7, 91-98.

Galimany, E., Sunila, I., Hégaret, H., Ramón, M., Wikfors, G.H., 2008b. Experimental exposure of the blue mussel (Mytilus edulis, L.) to the toxic dinoflagellate Alexandrium fundyense: Histopathology, immune responses, and recovery. Harmful Algae 7, 702-711. 
Galimany, E., Sunila, I., Hégaret, H., Ramón, M., Wikfors, G.H., 2008c. Pathology and immune response of the blue mussel (Mytilus edulis L.) after an exposure to the harmful dinoflagellate Prorocentrum minimum. Harmful Algae 7, 630-638.

Gill, S., Murphy, M., Clausen, J., Richard, D., Quilliam, M., Mackinnon, S., Lablanc, P., Mueller, R., Pulido, O., 2003. Neural injury biomarkers of novel shellfish toxins, spirolides: A pilot study using immunochemical and transcriptional analysis. Neurotoxicology 24, 593-604.

Guévélou, E., Huvet, A., Sussarellu, R., Milan, M., Guo, X., Li, L., Zhang, G., Quillien, V., Daniel, J.Y., Quéré, C., Boudry, P., Corporeau, C., 2013. Regulation of a truncated isoform of AMPactivated protein kinase $\alpha(\mathrm{AMPK} \alpha)$ in response to hypoxia in the muscle of Pacific oyster Crassostrea gigas. J. Comp. Physiol. B 183, 597-611.

Guillard, R.R.L., Hargraves, P.E., 1993. Stichochrysis immobilis is a diatom, not a chrysophyte. Phycologia 32, 234-236.

Guillard, R.R.L., Ryther, J.H., 1962. Studies of marine planktonic diatoms. I. Cyclotella nana Hustedt, and Detonula confervacea Cleve. Can. J. Microbiol. 8, 229-239.

Haberkorn, H., Lambert, C., Le Goïc, N., Guéguen, M., Moal, J., Palacios, E., Lassus, P., Soudant, P., 2010a. Effects of Alexandrium minutum exposure upon physiological and hematological variables of diploid and triploid oysters, Crassostrea gigas. Aquat. Toxicol. 97, 96-108.

Haberkorn, H., Lambert, C., Le Goïc, N., Moal, J., Suquet, M., Guéguen, M., Sunila, I., Soudant, P., 2010b. Effects of Alexandrium minutum exposure on nutrition-related processes and reproductive output in oysters Crassostrea gigas. Harmful Algae 9, 427-439.

Haberkorn, H., Tran, D., Massabuau, J.C., Ciret, P., Savar, V., Soudant, P., 2011. Relationship between valve activity, microalgae concentration in the water and toxin accumulation in the digestive gland of the Pacific oyster Crassostrea gigas exposed to Alexandrium minutum. Mar. Pollut. Bull. 62, 1191-1197.

Hauser, T.A., Hepler, C.D., Kombo, D.C., Grinevich, V.P., Kiser, M.N., Hooker, D.N., Zhang, J., Mountfort, D., Selwood, A., Akireddy, S.R., Letchworth, S.R., Yohannes, D., 2012. Comparison of acetylcholine receptor interactions of the marine toxins, 13-desmethylspirolide $\mathrm{C}$ and gymnodimine. Neuropharmacology 62, 2239-2250. 
Hégaret, H., Brokordt, K.B., Gaymer, C.F., Lohrmann, K.B., Garcia, C., Varela, D., 2012. Effects of the toxic dinoflagellate Alexandrium catenella on histopathogical and escape responses of the Northern scallop Argopecten purpuratus. Harmful Algae 18, 74-83.

Hégaret, H., da Silva, P.M., Sunila, I., Shumway, S.E., Dixon, M.S., Alix, J., Wikfors, G.H., Soudant, P., 2009. Perkinsosis in the Manila clam Ruditapes philippinarum affects responses to the harmful-alga, Prorocentrum minimum. J. Exp. Mar. Bio. Ecol. 371, 112-120.

Hégaret, H., da Silva, P.M., Wikfors, G.H., Lambert, C., De Bettignies, T., Shumway, S.E., Soudant, P., 2007a. Hemocyte responses of Manila clams, Ruditapes philippinarum, with varying parasite, Perkinsus olseni, severity to toxic-algal exposures. Aquat. Toxicol. 84, 469-479.

Hégaret, H., Wikfors, G.H., 2005a. Effects of natural and field-simulated blooms of the dinoflagellate Prorocentrum minimum upon hemocytes of eastern oysters, Crassostrea virginica, from two different populations. Harmful Algae 4, 201-209.

Hégaret, H., Wikfors, G.H., 2005b. Time-dependent changes in hemocytes of eastern oysters, Crassostrea virginica, and northern bay scallops, Argopecten irradians irradians, exposed to a cultured strain of Prorocentrum minimum. Harmful Algae 4, 187-199.

Hégaret, H., Wikfors, G.H., Shumway, S.E., 2007b. Diverse feeding responses of five species of bivalve mollusc when exposed to three species of harmful algae. J. Shellfish Res. 26, 549-559.

Hégaret, H., Wikfors, G.H., Soudant, P., Lambert, C., Shumway, S.E., Bérard, J.B., Lassus, P., 2007c. Toxic dinoflagellates (Alexandrium fundyense and A. catenella) have minimal apparent effects on oyster hemocytes. Mar. Biol. 152, 441-447.

Howard, D.W., Lewis, E.J., Keller, B.J., Smith, C.S., 2004. Histological techniques for marine bivalve mollusks and crustaceans. NOAA Tech. Memo. NOS NCCOS 5, 218.

Hu, T., Curtis, J.M., Oshima, Y., Quilliam, M.A., Walter, J.A., Watson-Wright, W.M., Wright, J.L.C., 1995. Spirolides B and D, two novel macrocycles isolated from the digestive glands of shellfish. J. Chem. Soc. Chem. Commun. 97, 2159-2161.

Landsberg, J.H., 2002. The effects of harmful algal blooms on aquatic organisms. Rev. Fish. Sci. 10, 113-390. 
Lee, M.K., Cho, B.Y., Lee, S.J., Kang, J.Y., Jeong, H.D., Huh, S.H., Huh, M.D., 2001. Histopathological lesions of Manila clam, Tapes philippinarum, from Hadong and Namhae coastal areas of Korea. Aquaculture 201, 199-209.

Lehmann, D.W., Levine, J.F., Law, J.M., 2007. Polychlorinated biphenyl exposure causes gonadal atrophy and oxidative stress in Corbicula fluminea clams. Toxicol. Pathol. 35, 356-365.

Lelong, A., Haberkorn, H., Le Goïc, N., Hégaret, H., Soudant, P., 2011. A new insight into allelopathic effects of Alexandrium minutum on photosynthesis and respiration of the diatom Chaetoceros neogracile revealed by photosynthetic-performance analysis and flow cytometry. Microb. Ecol. 62, 919-930.

Leverone, J.R., Shumway, S.E., Blake, N.J., 2007. Comparative effects of the toxic dinoflagellate Karenia brevis on clearance rates in juveniles of four bivalve molluscs from Florida, USA. Toxicon 49, 634-645.

Lowry, O.H., Rosebrough, N.J., Farr, A.L., Randall, R.J., 1951. Protein measurement with the Folin phenol reagent. J. Biol. Chem. 193, 265-275.

Manduzio, H., Rocher, B., Durand, F., Galap, C., Leboulenger, F., 2005. The point about oxidative stress in molluscs. Invertebr. Surviv. J. 2, 91-104.

Medhioub, W., Lassus, P., Truquet, P., Bardouil, M., Amzil, Z., Sechet, V., Sibat, M., Soudant, P., 2012. Spirolide uptake and detoxification by Crassostrea gigas exposed to the toxic dinoflagellate Alexandrium ostenfeldii. Aquaculture 358-359, 108-115.

Mello, D.F., da Silva, P.M., Barracco, M.A., Soudant, P., Hégaret, H., 2013. Effects of the dinoflagellate Alexandrium minutum and its toxin (saxitoxin) on the functional activity and gene expression of Crassostrea gigas hemocytes. Harmful Algae 26, 45-51.

Mello, D.F., de Oliveira, E.S., Vieira, R.C., Simoes, E., Trevisan, R., Dafre, A.L., Barracco, M.A., 2012. Cellular and transcriptional responses of Crassostrea gigas hemocytes exposed in vitro to brevetoxin (PbTx-2). Mar. Drugs 10, 583-597.

Montes, J.F., Durfort, M., García-Valero, J., 1995. Cellular defence mechanism of the clam Tapes semidecussatus against infection by the protozoan Perkinsus sp. Cell Tissue Res. 279, 529-538. 
Montes, J.F., Durfort, M., García-Valero, J., 1996. When the venerid clam Tapes decussatus is parasitized by the protozoan Perkinsus sp. it synthesizes a defensive polypeptide that is closely related to p225. Dis. Aquat. Organ. 26, 149-157.

Morado, J.F., Mooney, L.L., 1997. Observations on the histopathology of bay mussels, Mytilus trossulus: oil assessment studies in Prince William Sound Alaska. J. Shellfish Res. 16, 350-351.

Munday, R., Quilliam, M.A., LeBlanc, P., Lewis, N., Gallant, P., Sperker, S.A., Ewart, H.S., MacKinnon, S.L., 2012. Investigations into the toxicology of spirolides, a group of marine phycotoxins. Toxins (Basel). 4, 1-14.

Navas, J.I., Castillo, M.C., Vera, P., Ruiz-Rico, M., 1992. Principal parasites observed in clams, Ruditapes decussatus (L.), Ruditapes philippinarum (Adams et Reeve), Venerupis pullastra (Montagu) and Venerupis aureus (Gmelin), from the Huelva coast (S.W. Spain). Aquaculture 107, 193-199.

Ogata, T., Kodama, M., 1986. Ichthyotoxicity found in cultured media of Protogonyaulax spp. Mar. Biol. 92, 31-34.

Ordás, M.C., Gomez-Leon, J., Figueras, A., 2001. Histopathology of the infection by Perkinsus atlanticus in three clam species (Ruditapes decussatus, $R$. philippinarum and $R$. pullastra) from Galicia (NW Spain). J. Shellfish Res. 20, 1019-1024.

Otero, P., Alfonso, A., Rodríguez, P., Rubiolo, J.A., Manuel, J., Bermúdez, R., Vieytes, M.R., Botana, L.M., 2012. Pharmacokinetic and toxicological data of spirolides after oral and intraperitoneal administration. Food Chem. Toxicol. 50, 232-237.

Otero, P., Alfonso, A., Vieytes, M.R., Cabado, A.G., Vieites, J.M., Botana, L.M., 2010. Effects of environmental regimes on the toxin profile of Alexandrium ostenfeldii. Environ. Toxicol. Chem. $29,301-310$.

Park, K.I., Choi, K.S., 2001. Spatial distribution of the protozoan parasite Perkinsus sp. found in the Manila clams, Ruditapes philippinarum, in Korea. Aquaculture 203, 9-22.

Ray, S.M., 1966. A review of the culture method for detecting Dermocystidium marinum, with suggested modifications and precautions. Proc. Natl. Shellfish Assoc. 54, 55-69. 
Richard, D., Arsenault, E., Cembella, A., Quilliam, M., 2001. Investigations into the toxicology and pharmacology of spirolides, a novel group of shellfish toxins, in: Hallegraeff, G.M., Blackburn, S.I., Bolch, C.J., Lewis, R.J. (Eds.), Harmful Algal Blooms 2000. Intergovernmental Oceanographic Commission of UNESCO 2001, pp. 383-386.

Romero-Geraldo, R. de J., Hernández-Saavedra, N.Y., 2012. Stress gene expression in Crassostrea gigas (Thunberg, 1793) in response to experimental exposure to the toxic dinoflagellate Prorocentrum lima (Ehrenberg) Dodge, 1975. Aquac. Res. 1-11. doi: 10.1111/are.12100

Sagrista, E., Durfort, M., Azevedo, C., 1995. Perkinsus sp. (Phylum Apicomplexa) in Mediterranean clam Ruditapes semidecussatus: ultrastructural observations of the cellular response of the host. Aquaculture 132, 153-160.

Sanchez, F., Caill-Milly, N., De Casamajor, M.-N., Lissardy, M., 2013. Campagne d'évaluation du stock de palourdes du bassin d'Arcachon - Année 2012, Ifremer.

Shaw, B.L., Battle, H.I., 1957. The gross and microscopic anatomy of the digestive tract of the oyster Crassostrea virginica (Gmelin). Can. J. Zool. 35, 325-347.

Shumway, S.E., 1990. A review of the effects of algal blooms on shellfish and aquaculture. J. World Aquac. Soc. 21, 65-104.

Shumway, S.E., Cucci, T.L., 1987. The effects of the toxic dinoflagellate Protogonyaulax tamarensis on the feeding and behaviour of bivalve molluscs. Aquat. Toxicol. 10, 9-27.

Simonsen, S., Moller, B.L., Larsen, J., Ravn, H., 1995. Haemolytic activity of Alexandrium tamarense cells, in: Lassus, P., Arzul, G., Erard-Le Denn, E., Gentien, P., Marcaillou-Le Baut, C. (Eds.), Harmful Marine Algal Blooms. Lavoisier, Paris, pp. 513-517.

Smolowitz, R.M., Leavitt, D., 1996. Neoplasia and other pollution associated lesions in Mya arenaria from Boston Harbor. J. Shellfish Res. 15, 520.

Song, L., Wang, L., Qiu, L., Zhang, H., 2010. Bivalve Immunity, in: Söderhäll, K. (Ed.), Invertrebrate Immunity - Advances in Experimental Medicine and Biology 708. Landes Bioscience and Springer Science+Business Media, LLC, New York, NY, USA, pp. 44-65.

Soudant, P., Chu, F.L., Volety, A., 2013. Host-parasite interactions: Marine bivalve molluscs and protozoan parasites, Perkinsus species. J. Invertebr. Pathol. 114, 196-216. 
Soudant, P., Paillard, C., Choquet, G., Lambert, C., Reid, H.I., Marhic, A., Donaghy, L., Birbeck, T.H., 2004. Impact of season and rearing site on the physiological and immunological parameters of the Manila clam Venerupis (=Tapes, = Ruditapes) philippinarum. Aquaculture 229, 401-418.

Stowe, D.F., Camara, A.K.S., 2009. Mitochondrial reactive oxygen species production in excitable cells: modulators of mitochondrial and cell function. Antioxid. Redox Signal. 11, 1373-1414.

Tillmann, U., John, U., Cembella, A., 2007. On the allelochemical potency of the marine dinoflagellate Alexandrium ostenfeldii against heterotrophic and autotrophic protists. J. Plankton Res. 29, 527-543.

Tran, D., Haberkorn, H., Soudant, P., Ciret, P., Massabuau, J.-C., 2010. Behavioral responses of Crassostrea gigas exposed to the harmful algae Alexandrium minutum. Aquaculture 298, 338345 .

Villalba, A., Casas, S.M., López, C., Carballal, M.J., 2005. Study of perkinsosis in the carpet shell clam Tapes decussatus in Galicia (NW Spain). II. Temporal pattern of disease dynamics and association with clam mortality. Dis. Aquat. Organ. 65, 257-267.

Villalba, A., Reece, K.S., Ordás, M.C., Casas, S.M., Figueras, A., 2004. Perkinsosis in molluscs: A review. Aquat. Living Ressources 17, 411-432.

Waki, T., Shimokawa, J., Watanabe, S., Yoshinaga, T., Ogawa, K., 2012. Experimental challenges of wild Manila clams with Perkinsus species isolated from naturally infected wild Manila clams. J. Invertebr. Pathol. 111, 50-55.

Waki, T., Yoshinaga, T., 2013. Experimental challenges of juvenile and adult Manila clams with the protozoan Perkinsus olseni at different temperatures. Fish. Sci. 79, 779-786.

Wandscheer, C.B., Vilarin, N., Louzao, M.C., Botana, L.M., 2010. Human muscarinic acetylcholine receptors are a target of the marine toxin 13-desmethyl C spirolide. Chem. Res. Toxicol. 23, $1753-1761$.

Yang, H.-S., Park, K.-I., Donaghy, L., Adhya, M., Choi, K.-S., 2012. Temporal variation of Perkinsus olseni infection intensity in the Manila Clam Ruditapes philippinarum in Gomso Bay, off the West coast of Korea. J. Shellfish Res. 31, 685-690. 
Yin, D., 1996. Biochemical basis of lipofuscin, ceroid, and age pigment-like fluorophores. Free Radic. Biol. Med. 21, 871-888.

Zaroogian, G., Anderson, S., 1995. Comparison of cadmium, nickel and benzo(a)pyrene uptake into cultured brown cells of the hard shell clam, Mercenaria mercenaria. Comp. Biochem. Physiol. Part C 111, 109-116.

Zaroogian, G., Yevich, P., 1994. The nature and function of the brown cell in Crassostrea virginica. Mar. Environ. Res. 37, 355-373.

Zaroogian, G., Yevich, P., Pavignano, S., 1989. The role of the red gland in Mercenaria mercenaria in detoxification. Mar. Environ. Res. 28, 447-450. 
Figure 1. Spirolide analogue content in digestive gland and in the remaing tissues of Manila clams $V$. philippinarum exposed to a mix of T-Iso and A. ostenfeldii for 7 days ("Exposure"), followed by 7 days of depuration fed T-Iso ("Depuration"). Error bars represent standard errors of total spirolide content. Significant differences in total spirolide content between exposure vs. depuration in each tissue are indicated by $*$ : $\mathrm{p}<0.05$ (t-test). $\mathrm{N}=8$ in each group.

Figure 2. Circulating hemocyte variables of Manila clams V. philippinarum exposed to T-Iso (control) or to a mix of T-Iso and A. ostenfeldii. (A): Size of hemocytes ( $\mathrm{n}=21-24$ per group) and (B): mitochondrial membrane potential (MMP; $n=8-16$ per group) after 7 days of dinoflagellate exposure ("Exposure") and after 7 days of depuration with the diet T-Iso ("Depuration"); (C): Hemocyte ROS production according to algal treatment and to P. olseni burden ("Very light-Light" or "ModerateHeavy"), over 7 days of dinoflagellate exposure followed by 7 days of depuration with the diet T-Iso $(\mathrm{n}=17-24$ per group). Error bars represent standard errors. * and letters indicate significant difference between groups, NS indicates no significant difference (ANOVA followed by post-hoc Tukey HSD test, $\alpha=0.05$ ). a.u.: arbitrary units.

Figure 3. Specific activity of antioxidant enzymes of Manila clams V. philippinarum exposed to T-Iso (control) or to a mix of T-Iso and A. ostenfeldii. (A): SOD specific activity after exposure and after depuration (n=8-11 per group); (B): CAT specific activity according to algal treatment and P. olseni burden ("Very light-Light" or "Moderate-Heavy"), over 7 days of algal exposure followed by 7 days of depuration with T-Iso ( $\mathrm{n}=9-11$ per group); Error bars represent standard errors. * and letters indicate significant difference between groups, NS indicates no significant difference (ANOVA followed by post-hoc Tukey HSD test, $\alpha=0.05$ ).

Figure 4. Histopathological conditions. (A): Gills of control clam; (B): Vacuolation (1) of gill filaments in A. ostenfeldii-exposed clam; (C): Brown cells (2) in gills of A. ostenfeldii-exposed clam (D): Intestinal epithelium of control clam; (E): Diapedesis of hemocytes (3) in intestinal epithelium and A. ostenfeldii cell (4) in intestinal lumen of A. ostenfeldii-exposed clam; (F): A. ostenfeldii cells (5) in digestive tubule lumen of one A. ostenfeldii-exposed clam; (G): Digestive tubule of a control clam; (H): Vacuolation (6) in the digestive tubule of "Moderately-Heavily" P. olseni-infected clam; (I): Hemocytic encapsulation (7) of P. olseni trophozoites (8) in connective tissue of the digestive gland. 
Figure 5. Intensity of histopathological features (semi-quantitative scale) in tissues of Manila clams $V$. philippinarum, from two different algal treatments, T-Iso (control) or a mix of T-Iso and A. ostenfeldii, after 7 days of exposure and after 7 more days of depuration. Error bars represent standard errors. Significant differences between control ("T-Iso") and exposed clams ("A. ostenfeldii") are indicated by \#: $\mathrm{p}<0.1$ and $*$ : $\mathrm{p}<0.05$, and NS indicates no significant difference (Mann-Whitney test). N=4-8 per group. (A): Hemocyte infiltration in gills; (B): Edema in mantle; (C): Epithelium sloughing into the intestinal lumen; (D): Vacuolation in gill filaments; (E): Brown cells in gills; (F): Hemocytes in intestinal lumen. 
Table 1. Semi-quantitative scale categorizing intensity of histopathological conditions observed

\begin{tabular}{ll}
\hline \hline $\begin{array}{l}\text { Level } \\
\text { intensity }\end{array}$ & Occurrence of the pathological condition in the examined tissue area \\
\hline 0 & Absence \\
0.5 & Very low $(1-5$ total occurrence) \\
1 & Low (> 5 occurrence / presence in all fields at magnification $10 \mathrm{x})$ \\
1.5 & Moderate (presence in all fields at magnification $20 \mathrm{x} /$ covering about $10 \%$ of the tissue) \\
2 & $\begin{array}{l}\text { High (presence in all fields at magnification } 40 \mathrm{x} / \text { covering about } 20 \% \text { of the tissue) } \\
\text { Very high (presence in all fields at magnification } 60 \mathrm{x} / \text { covering about } 30 \% \text { or above of }\end{array}$ \\
\hline \hline
\end{tabular}


Table 2. Comparison of physiological variables measuredin $V$. philippinarum (i) over the entire experiment, (ii) after 7 days of exposure to $A$. ostenfeldii or to control T-Iso, and (iii) after 7 days of depuration (fed only T-Iso). NS: No significant difference; *Significant difference indicated by $p<0.05$; ** Significant difference indicated by $p<0.01$ (2-way ANOVA); "-": no analysis over the entire experiment because there was a significant effect of time of sampling (exposure vs. depuration); between brackets: significant effect after exposure and after depuration are indicated separately because of the absence of analysis over the entire experiment since there was a significant effect of time of sampling (exposure vs. depuration).

\begin{tabular}{|c|c|c|c|c|c|c|c|c|c|c|}
\hline \multirow{3}{*}{$\begin{array}{l}\text { Physiological } \\
\text { parameters }\end{array}$} & \multicolumn{6}{|c|}{ Over the entire experiment } & \multicolumn{2}{|c|}{$\begin{array}{l}\text { After seven days } \\
\text { of exposure }\end{array}$} & \multicolumn{2}{|c|}{$\begin{array}{l}\text { After seven days } \\
\text { of depuration }\end{array}$} \\
\hline & \multicolumn{2}{|c|}{$\begin{array}{l}\text { Factor algal } \\
\text { treatment }\end{array}$} & \multicolumn{2}{|c|}{$\begin{array}{l}\text { Factor } P \text {. olseni } \\
\text { burden }\end{array}$} & \multicolumn{2}{|c|}{ Interaction } & \multicolumn{2}{|c|}{$\begin{array}{l}\text { Factor algal } \\
\text { treatment }\end{array}$} & \multicolumn{2}{|c|}{$\begin{array}{l}\text { Factor algal } \\
\text { treatment }\end{array}$} \\
\hline & p & $\mathrm{n}$ & p & n & p & $\mathrm{n}$ & p & n & p & n \\
\hline Condition index & NS & 44 & NS & 44 & NS & $21-23$ & NS & $23-24$ & NS & $20-21$ \\
\hline \multicolumn{11}{|c|}{ Hemocyte and plasma parameters } \\
\hline $\begin{array}{l}\text { Phagocytosis (\% of } \\
\text { phagocyting } \\
\text { hemocytes) }\end{array}$ & - & - & $\begin{array}{l}\text { (NS; } \\
\text { NS) }\end{array}$ & $\begin{array}{l}(18-27 ; \\
16-26)\end{array}$ & $\begin{array}{l}\text { (NS; } \\
\text { NS) }\end{array}$ & $\begin{array}{l}(8-16 ; \\
8-13)\end{array}$ & NS & $21-24$ & NS & 21 \\
\hline Mortality of hemocytes & - & - & $\begin{array}{l}\text { (NS; } \\
\text { NS) }\end{array}$ & $\begin{array}{l}(16-27 ; \\
16-27)\end{array}$ & $\begin{array}{l}\text { (NS; } \\
\text { NS) }\end{array}$ & $\begin{array}{l}(8-16 ; \\
8-15)\end{array}$ & NS & $19-24$ & NS & $20-23$ \\
\hline $\begin{array}{l}\text { Hemocyte ROS } \\
\text { production }\end{array}$ & NS & $31-47$ & $=$ & $38-40$ & * & $17-24$ & NS & $15-24$ & NS & $16-23$ \\
\hline Hemocyte MMP & - & - & $\begin{array}{l}\text { (NS; } \\
\text { NS) }\end{array}$ & $\begin{array}{l}(18-29 ; \\
16-28)\end{array}$ & $\begin{array}{l}\text { (NS; } \\
\text { NS) }\end{array}$ & $\begin{array}{l}(8-16 ; \\
8-15)\end{array}$ & 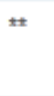 & $23-24$ & NS & $21-23$ \\
\hline THC & NS & $40-47$ & NS & $43-44$ & NS & $19-24$ & NS & $20-24$ & NS & $20-23$ \\
\hline Size of hemocytes & $\star \star$ & $44-47$ & \pm & $45-46$ & NS & $21-24$ & $*$ & $23-24$ & NS & $21-23$ \\
\hline $\begin{array}{l}\text { Complexity of } \\
\text { hemocytes }\end{array}$ & NS & $44-47$ & NS & $45-46$ & NS & $21-24$ & NS & $23-24$ & NS & $21-23$ \\
\hline Agglutination titer & NS & $32-43$ & NS & $37-38$ & NS & $15-23$ & NS & $17-23$ & NS & $15-20$ \\
\hline Hemolysis titer & - & - & $\begin{array}{l}\text { (NS; } \\
\text { NS) }\end{array}$ & $\begin{array}{l}(16-24 ; \\
14-21)\end{array}$ & $\begin{array}{l}\text { (NS; } \\
\text { NS) }\end{array}$ & $\begin{array}{l}(8-16 ; \\
6-12)\end{array}$ & NS & $17-23$ & NS & $15-20$ \\
\hline \multicolumn{11}{|c|}{ Antioxidant enzymes specific activity (gills) } \\
\hline CAT & NS & 20 & NS & 20 & * & $9-11$ & NS & $9-10$ & NS & $10-11$ \\
\hline Total SOD & $\star \star$ & $19-21$ & NS & $19-21$ & NS & $9-12$ & NS & $9-10$ & * & $10-11$ \\
\hline $\mathrm{Cu} / \mathrm{Zn}$ SOD & * & $17-20$ & NS & $17-20$ & NS & 8-11 & NS & $8-9$ & NS & 9-11 \\
\hline Mn SOD & $\star \star$ & $17-20$ & NS & $17-20$ & NS & 8-11 & NS & $8-9$ & * & $9-11$ \\
\hline \multicolumn{11}{|c|}{ Digestive enzyme specific activity (digestive gland) } \\
\hline Amylase & NS & $12-14$ & NS & $11-15$ & NS & $5-9$ & NS & $6-7$ & NS & $8-5$ \\
\hline Cellulase & NS & $12-14$ & NS & $11-15$ & NS & $5-9$ & NS & $6-7$ & NS & $8-5$ \\
\hline Laminarinase & NS & $12-14$ & NS & $11-15$ & NS & $5-9$ & NS & $6-7$ & NS & $8-5$ \\
\hline
\end{tabular}

ROS: reactive oxygen species; MMP: mitochondrial membrane potential; THC: total hemocyte count; CAT: Catalase; SOD: Superoxide Dismutase. 
Table 3. Comparison of histological features in experimental clams, according to P. olseni burden categories ("Very light-Light" vs "Moderate-High"), and upon algal treatment (mix of T-Iso and A. ostenfeldii vs control T-Iso) after 7 days of exposure ("Exposure"), after 7 days of depuration (fed only T-Iso) ("Depuration"), and during the entire course of the experiment (Exposure + Depuration). NS: no significant difference. Significant differences indicated by \#: $\mathrm{p}<0.1 ; *$ : $\mathrm{p}<0.05 ; * *$ : $<<0.01$ (MannWhitney test). $\dagger$ : a single clam showed this characteristic. $N A$ : not available (not enough data). "-”: no analysis over the entire course of the experiment because there was a significant effect of time of sampling (exposure vs. depuration). 


\begin{tabular}{|c|c|c|c|c|c|c|c|c|}
\hline \multirow[t]{3}{*}{ Histological features } & \multirow{2}{*}{\multicolumn{2}{|c|}{$\begin{array}{c}\text { Differences } \\
\text { between } \\
P . \text { olseni } \\
\text { burdens }\end{array}$}} & \multicolumn{6}{|c|}{ " Differences between algal treatments } \\
\hline & & & \multicolumn{2}{|c|}{ Exposure } & \multicolumn{2}{|c|}{ Depuration } & \multicolumn{2}{|c|}{$\begin{array}{c}\text { Over the } \\
\text { entire } \\
\text { experiment }\end{array}$} \\
\hline & $\mathbf{p}$ & $\mathbf{n}$ & $\mathbf{p}$ & $\mathbf{n}$ & $\mathbf{p}$ & $\mathbf{n}$ & $\mathbf{p}$ & $\mathbf{n}$ \\
\hline \multicolumn{9}{|l|}{ Hemocyte infiltration: } \\
\hline - gills & NS & 12 & $*$ & $5-7$ & NS & $5-7$ & - & - \\
\hline - mantle & NS & 11 & NS & 6 & NS & $4-6$ & - & \\
\hline - digestive gland & NS & 13 & \# & $5-7$ & NS & $6-8$ & $*$ & $11-15$ \\
\hline - digestive epithelium & NS & $12-14$ & NS & $5-7$ & NS & $6-8$ & NS & $11-15$ \\
\hline - gonadal tissue & NS & $13-14$ & NS & $6-7$ & NS & $6-8$ & NS & $12-15$ \\
\hline - adductor muscle & NS & $6-7$ & NA & & NS & $3-6$ & NS & $5-8$ \\
\hline Hemocyte encapsulation: & & & & & NS & 2 & & \\
\hline - gills & NS & $11-13$ & NS & 6 & NS & $5-7$ & NS & $11-13$ \\
\hline - mantle & NS & $9-11$ & NS & 5 & NS & $4-6$ & NS & $9-11$ \\
\hline - digestive gland & \# & $12-14$ & NS & $5-7$ & NS & $5-8$ & NS & $11-15$ \\
\hline - digestive epithelium & NS & 13 & NS & $6-7$ & NS & $5-8$ & NS & $11-15$ \\
\hline - gonadal tissue & \# & 13 & NS & $6-7$ & NS & $5-8$ & NS & $11-15$ \\
\hline - adductor muscle & NS & $8-10$ & NS & $3-5$ & $N A$ & & NS & $8-10$ \\
\hline Mantle: edema & NS & $11-12$ & $*$ & 6 & NS & $5-6$ & $*$ & $11-12$ \\
\hline \multicolumn{9}{|l|}{ Gills: } \\
\hline - edema & $\mathrm{NS}$ & $12-13$ & NS & $6-7$ & NS & $5-7$ & NS & $11-14$ \\
\hline - brown cells & NS & $12-13$ & NS & $6-7$ & \# & $5-7$ & NS & $11-14$ \\
\hline - vacuolation & NS & $12-13$ & NS & $6-7$ & \# & $5-7$ & \# & $11-14$ \\
\hline $\begin{array}{l}\text { Stomach: epithelium sloughing into } \\
\text { the lumen }\end{array}$ & NS & 13 & NS & $5-7$ & NS & $6-8$ & \# & $11-15$ \\
\hline \multicolumn{9}{|l|}{ Intestine: } \\
\hline - hemocyte diapedesis & $\mathrm{NS}$ & $12-13$ & NS & $4-7$ & NS & $6-8$ & $*$ & $10-15$ \\
\hline - brown cells through the epithelium & NS & $12-13$ & NS & $4-7$ & NS & $6-8$ & - & - \\
\hline - A. ostenfeldii cells in the lumen & NS & $12-13$ & $*$ & $4-7$ & \# & $6-8$ & $* *$ & $10-15$ \\
\hline - T-Iso cells in the lumen & NS & $12-13$ & NS & $4-7$ & NS & $6-8$ & NS & $10-15$ \\
\hline - brown cells in the lumen & $\mathrm{NS}$ & $12-13$ & NS & $4-7$ & NS & $6-8$ & - & - \\
\hline -epithelium sloughing into the lumen & NS & $12-13$ & $*$ & $4-7$ & NS & $6-8$ & - & - \\
\hline - hemocytes in the lumen & NS & $12-13$ & NS & $4-7$ & \# & $6-8$ & NS & $10-15$ \\
\hline \multicolumn{9}{|l|}{ Digestive tubules: } \\
\hline - hemocyte diapedesis & NS & $10-11$ & NS & $4-5$ & NS & $5-7$ & NS & $9-12$ \\
\hline - brown cells through the epithelium & NS & $10-11$ & NS & $4-5$ & NS & $5-7$ & - & - \\
\hline - A. ostenfeldii cells in lumen & NS & $10-11$ & $\mathrm{NS}+$ & $4-5$ & NS & $5-7$ & $\mathrm{NS}+$ & $9-12$ \\
\hline - brown cells in the lumen & NS & $10-11$ & NS & $4-5$ & NS & $5-7$ & - & - \\
\hline -epithelium sloughing into the lumen & $\mathrm{NS}$ & $10-11$ & NS & $4-5$ & NS & $5-7$ & NS & $9-12$ \\
\hline - hemocytes in the lumen & $\mathrm{NS}$ & $10-11$ & NS & $4-5$ & NS & $5-7$ & NS & $9-12$ \\
\hline - vesicles & NS & $10-11$ & NS & $4-5$ & NS & $5-7$ & NS & $9-12$ \\
\hline - vacuolation & \# & $10-11$ & NS & $4-5$ & NS & $5-7$ & NS & $9-12$ \\
\hline \multicolumn{9}{|l|}{ P. olseni cells: } \\
\hline - gills & NS & $12-13$ & NS & $6-7$ & NS & $5-7$ & \# & $11-14$ \\
\hline - mantle & NS & $11-12$ & $* *$ & 6 & NS & $4-7$ & - & - \\
\hline - digestive gland & $*$ & $13-14$ & NS & $6-7$ & NS & $6-8$ & NS & $12-15$ \\
\hline - gonadal tissue & $\mathrm{NS}$ & $13-14$ & NS & $6-7$ & NS & $6-8$ & NS & $12-15$ \\
\hline - adductor muscle & NS & $6-7$ & $N A$ & & $\#$ & $3-6$ & \# & $5-8$ \\
\hline
\end{tabular}




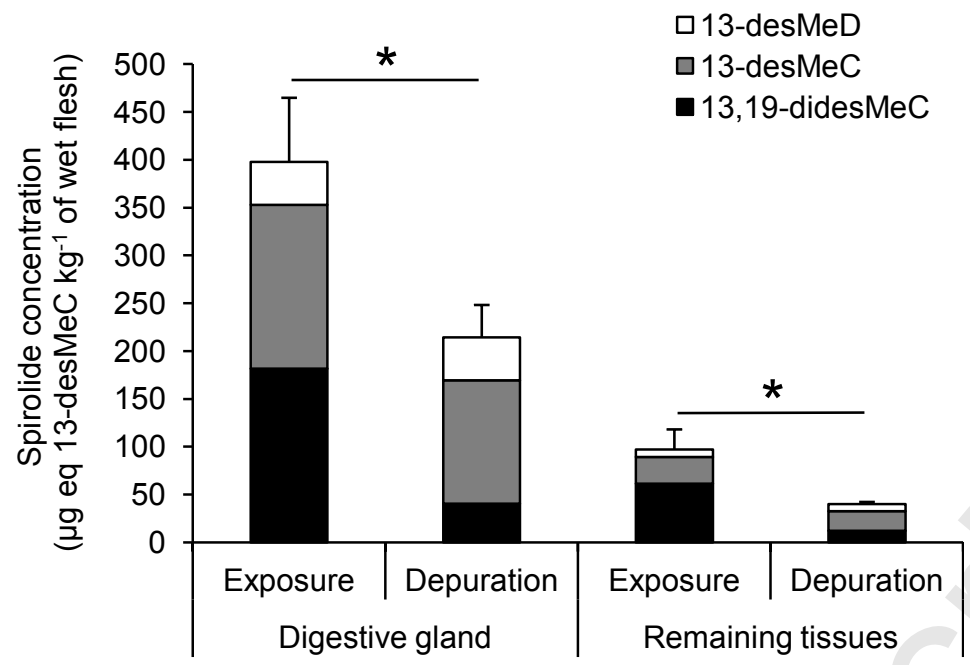


A

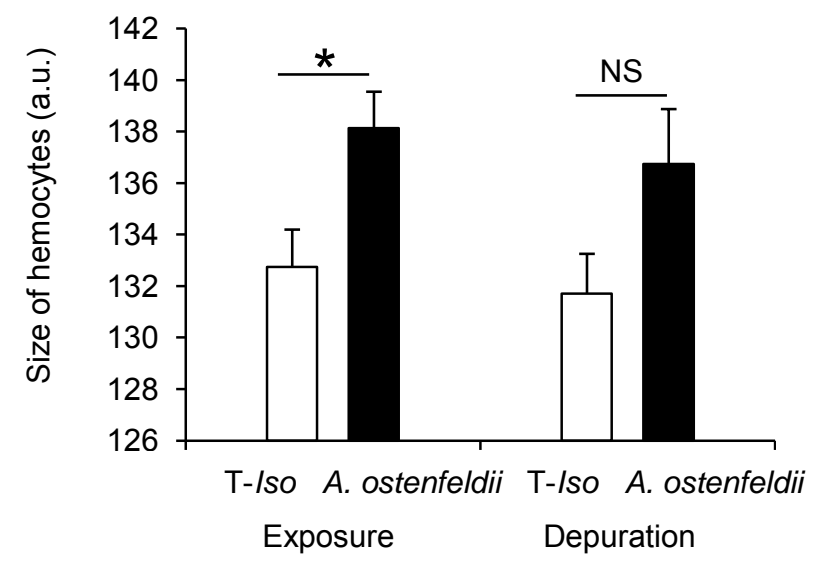

B

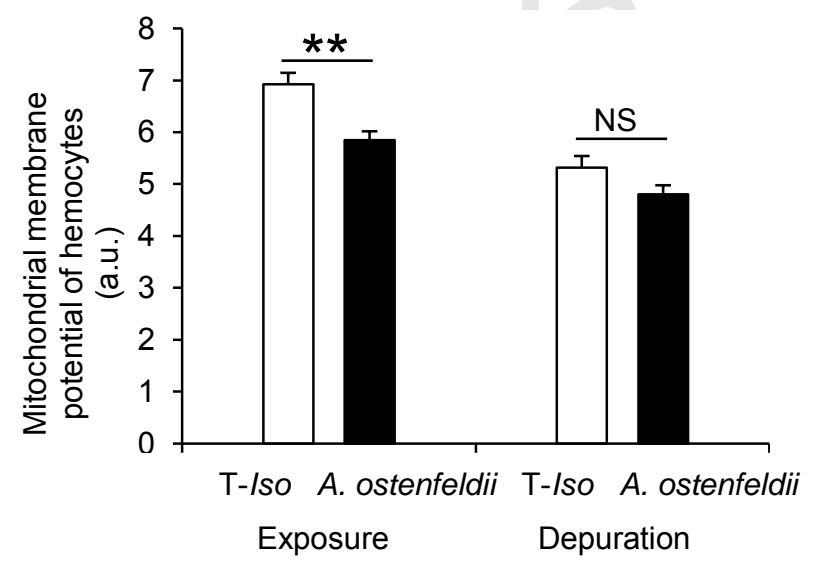

C

$\square$ Very light-Light infection $\square$ Moderate-High infection

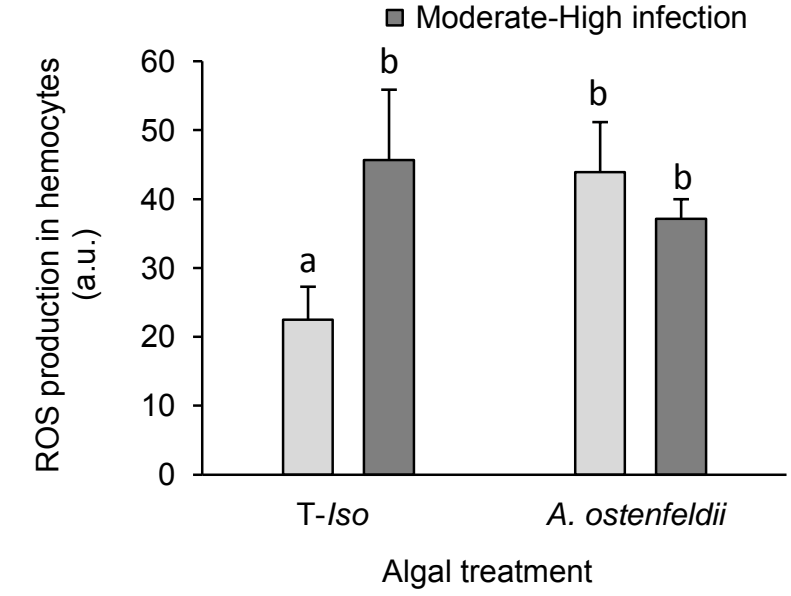


A

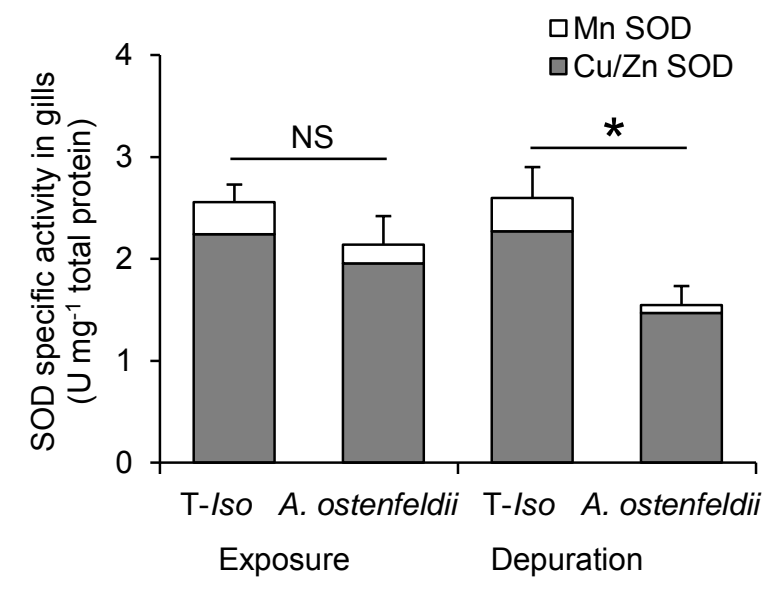

B

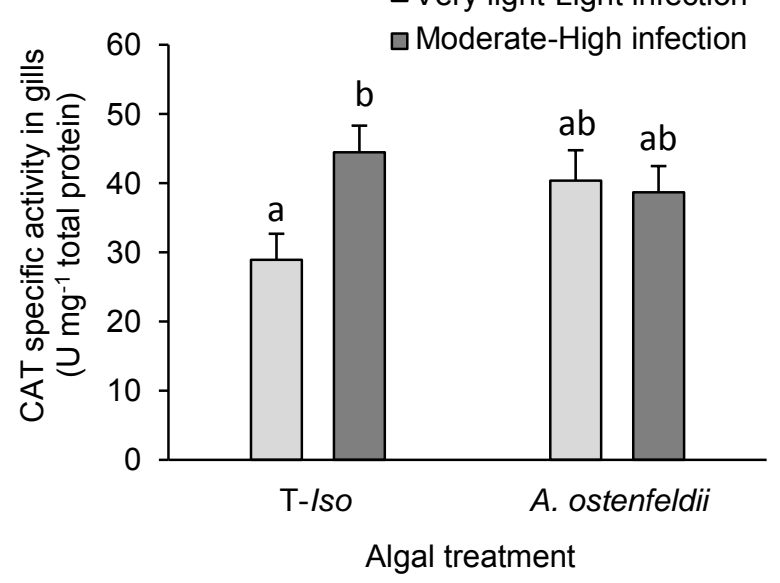




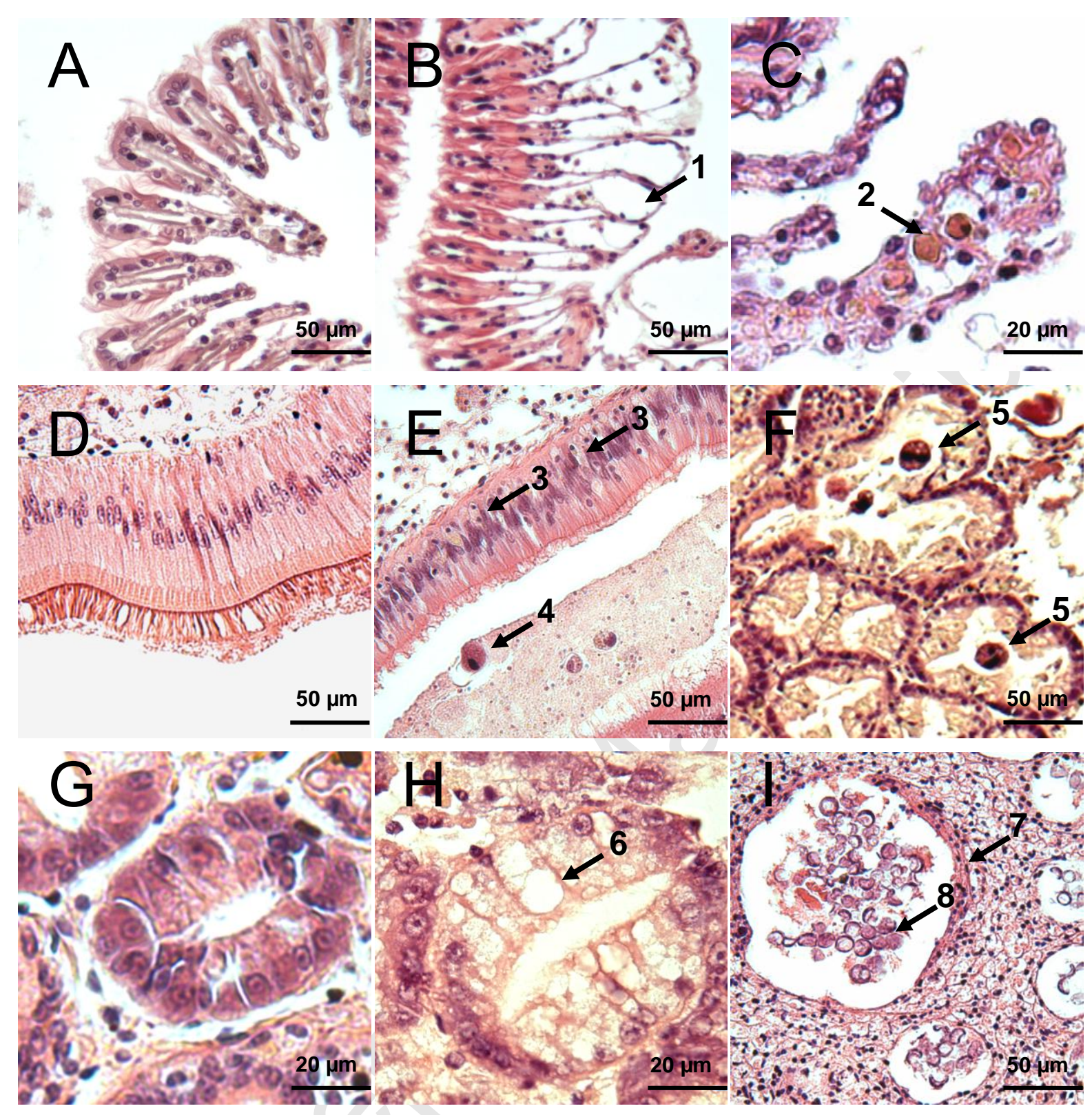



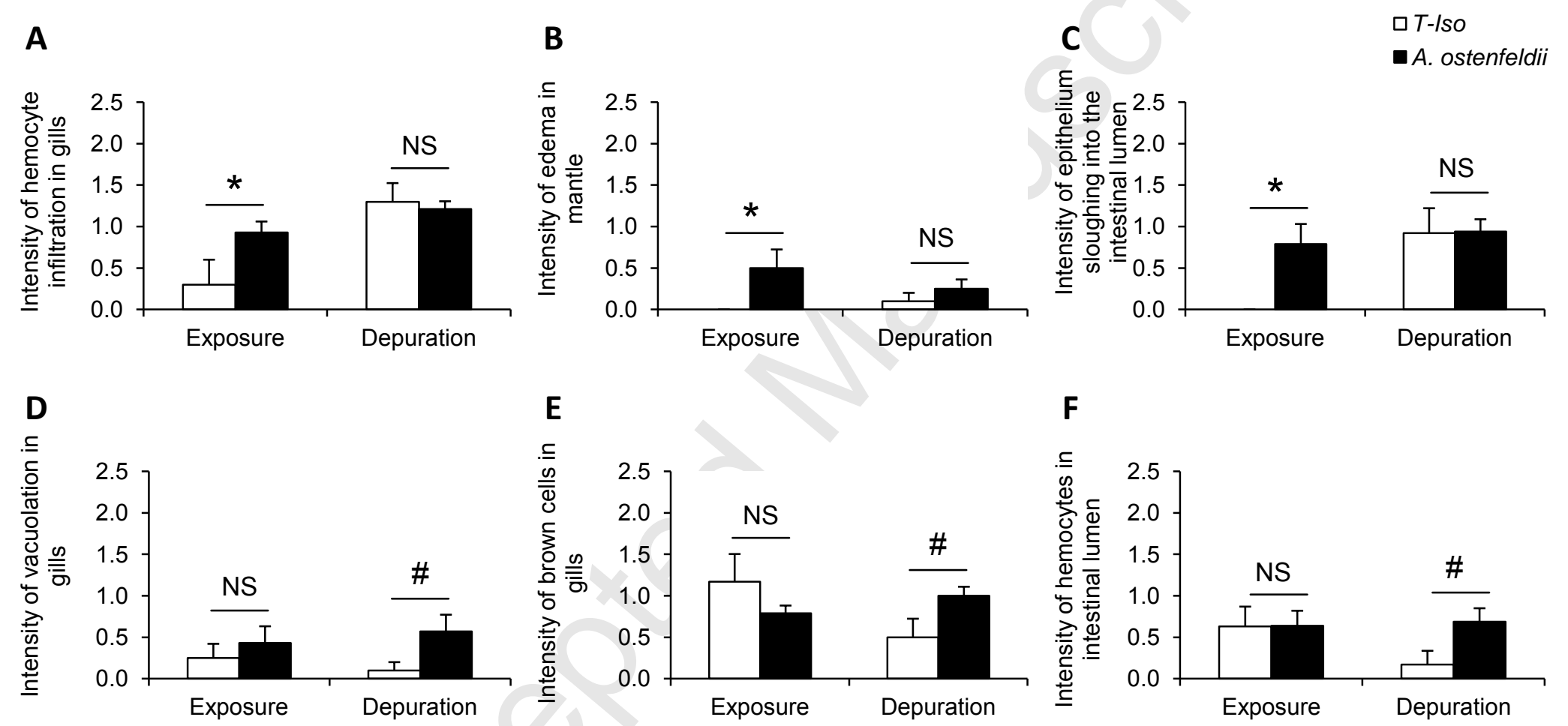